\title{
The Effect of Using Service Automation and Robotic Technologies (SART) in Egyptian Hotels
}

\section{Hany Atef Kozmal}

Head de[partment of hotel management the higher institute for tourism and hospitality management Egoth Luxor

\begin{tabular}{l} 
ARTICLE INFO \\
\hline Keywords: \\
Service automation; \\
Robotic technologies; \\
Guest' Satisfaction; \\
Customer Centric \\
Marketing; safety and \\
infections prevention .
\end{tabular}

\section{(JAAUTH) \\ Vol.19, No.2, (2020),} PP. 130-165.

\section{Abstract}

Introduction: Service automation and robotic technologies (SART) are now the most important strategic technologies for hospitality; satisfy guests, Employees' knowledge and efficiency: investigate SWOT" strategic planning analysis to evaluate the SART in Egyptian hotels.

Objectives: The research objective was to shed light on the importance of SART in Egyptian hotels and its policy in entitles workers to the importance of service automation and robotic in ensuring Guest' satisfaction and safety.

Methodology: A survey was carried out on (28) Five Star Egyptian hotels. Results: The major contribution findings of this research showed that the effectiveness of the SART in assessing decisions, Increase Guest Satisfaction in Egyptian hotels.

Recommendations: The study recommended the need to apply the SART in Egyptian hotels. Therefore, management should be sensitive to the SART applications that were already going on within the hotels and seek means to support them. Hotels management in Egypt should direct some of their budgets to SART.

\section{Research Objectives}

The research objective was to shed light on the importance of Customer- Centric Marketing (CCM) apps and practices in Egyptian hotels and its policy in entitles workers to the importance of the hotel practices in terms of enhancing the importance of SART in in Egyptian hotels by assuring guest' satisfaction and CCM. The research objectives are to:

1. Shed light on the benefits and importance of SART in Egyptian hotels.

2. Assessment the role of hotel management and its policy in entitles workers to the importance of the service automation Technologies and CCM apps and practices.

3. Enhancing the importance of SART in increasing the effectiveness of Egyptian hotel by increase Guest' Satisfaction and safety. 


\section{Research Conceptual Framework}

Study the SART as a tool to increase Guest' Satisfaction and safety in Egypt foundational processes based on the Assessment of Benefits, Reality and the predictable opportunities and threats of SART in the Egyptian hotels.

This section constructs a conceptual framework to explore the impacts of SART use in Egyptian hotels (Guest' Satisfaction, Employees' knowledge and efficiency, safety and CCM).

The framework comprises three parts regarding the SART. First part: (The benefits of automation and technologies). The second part "SWOT" Strategic Planning Analysis (the actual situation of SART; the strangeness and weakness points "reality"; the predictable opportunities and threats of SART). The third part is the impact on the Egyptian hotels (Guest' Satisfaction; Employees' knowledge and efficiency; safety and CCM).

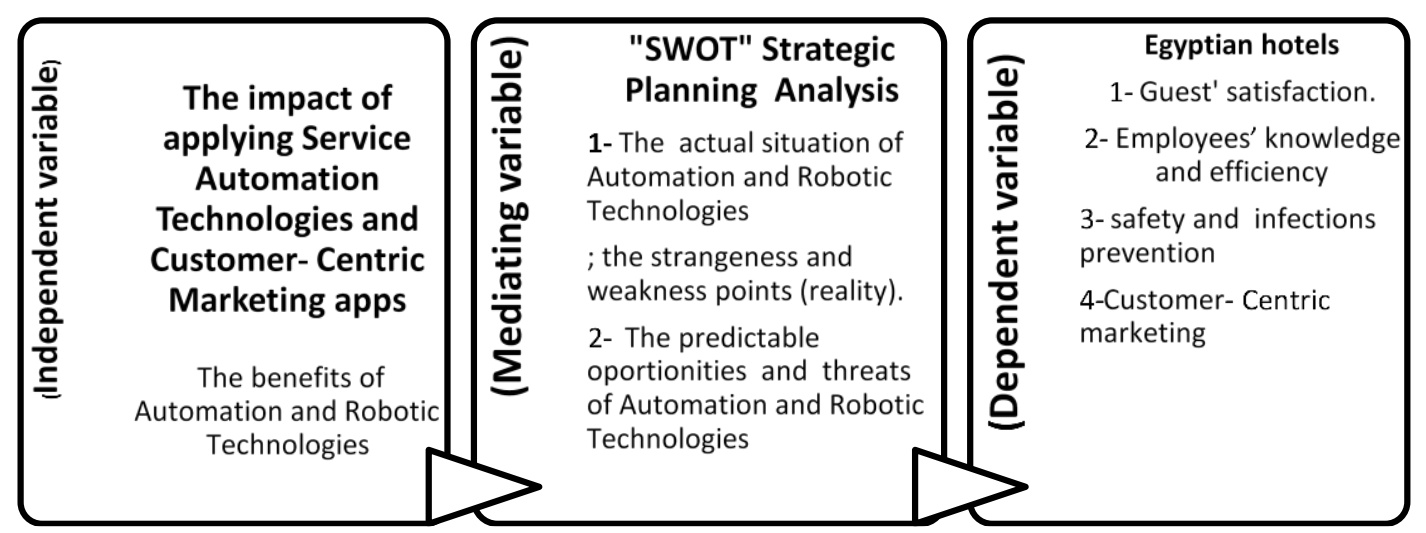

Figure.2. Research Conceptual Framework

\section{Research Hypotheses}

H1: There is a significant impact difference of applying SART in the development on the main variables of the study (Guest' Satisfaction; Employees' knowledge and efficiency; safety and CCM).

$\checkmark$ H1A: Applying the SART in the Egyptian hotels positively influences the Guest' Satisfaction.

$\checkmark$ H1B: Adapting appropriate system of SART positively influences Employees' knowledge and efficiency

$\checkmark$ H1C: Using SART positively influences safety and infections prevention.

$\checkmark$ H1D: Using SART positively influences CCM.

H2: There are significant relationships between the main variables of the study (Service automation and robotic; Guest' Satisfaction; Employees' knowledge and efficiency; safety and infections prevention; CCM). 


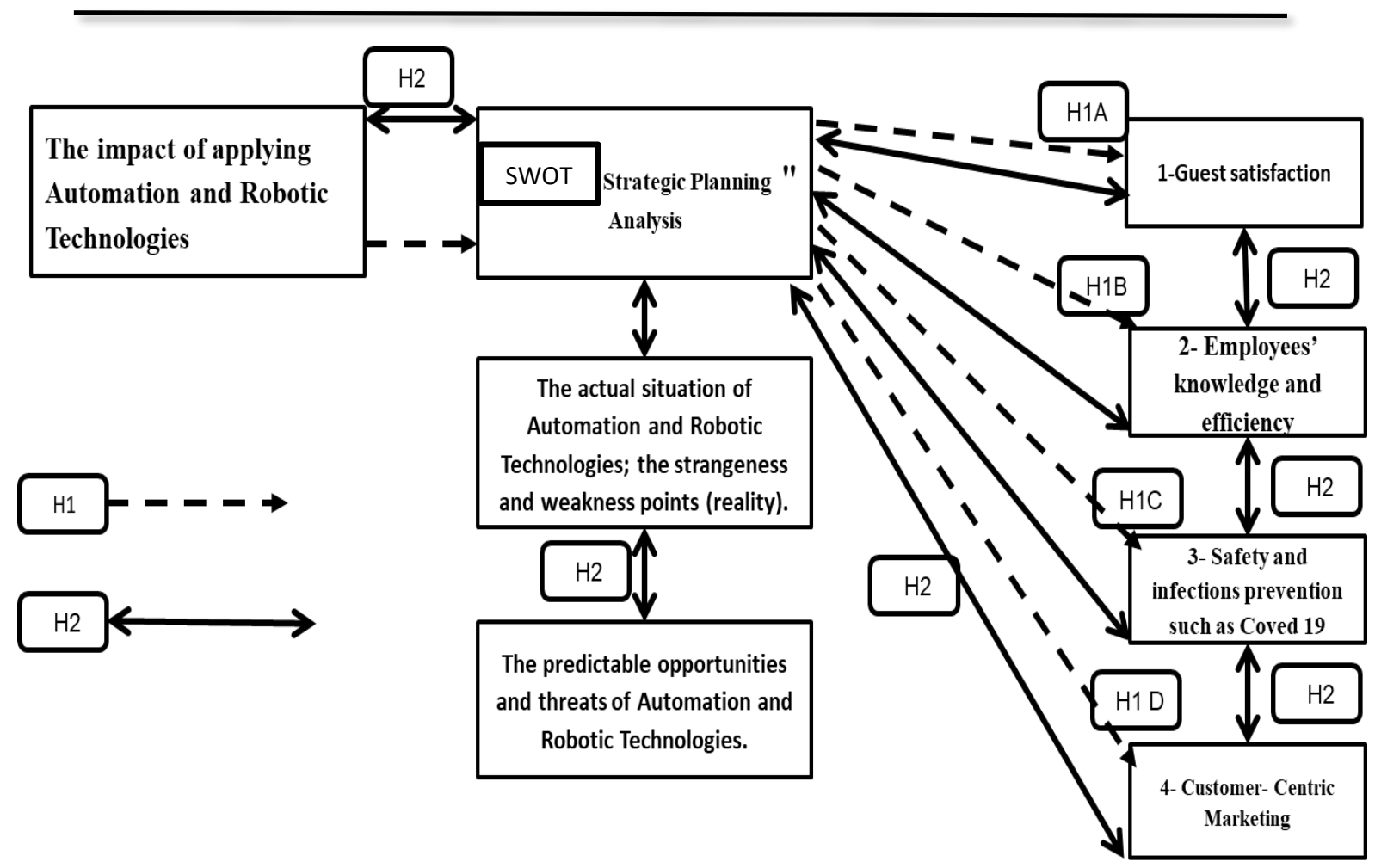

Figure.2. the research Hypotheses Framework

\section{Introduction and background}

Artificial intelligence, SART has arrived and became one of the important tools for success. The world has witnessed significant progress in Customer- Centric Marketing, robotics and service automation (Russell and Norvig, 2010; Kanda and Ishiguro, 2012; Warwick, 2012; Neapolitan and Jiang, 2013; Samani, 2016; Schmid and Betsch, 2019). Service Automation Technologies and Customer- Centric Marketing apps are used in the transportation as autonomous vehicles (Maurer et al., 2016), in education (Fridin and Belokopytov, 2014; Ivanov, 2016; Timms, 2016). Applications of artificial intelligence, Customer- Centric Marketing apps, service automation and robotics are everywhere (Kuo and Boger, 2016).

SART are entering travel, hospitality and hotels as well (Ritzer, 2015; Gladstone, 2016). A completely automated restaurant is also forthcoming in New York (Marks, 2016). Service automation and artificial intelligence provide vast opportunities to hotels to increase their operations and productivity deliver dependable product and service quality to the guests. While the application of artificial intelligence and Service Automation Technologies in hotels has received some attention by scholars (Borràs et al., 2014; Murphy et al., 2017 ${ }^{\mathrm{B}}$ ). For that, this research aims to focus on SWOT Strategic Planning Analysis of SART in Egyptian Hotels in order to increase guest' satisfaction.

\section{SART in Hotels}

SART support the lodging segment of the hotel and industry, affecting different areas of hotel operations (López et al., 2013; Rodriguez-Lizundia et al., 2015). Hotels implemented self-service kiosks that enable guests to offer the hospitality 
services such as: complete check-in and check-out (Kim and Qu, 2014). Check-in and /or out services were offered to guests on their mobile devices is improve convenience and service speed (e.g., Berezina, 2015; Hilton Honors, 2017; Marriott International, Inc., 2016; MGM Resorts International, 2017); mobile technology continues to develop to integrate mobile service ordering into a seamless hotel guest experience and placing requests right to guest fingertips (Trejos, 2015; Tussyadiah and Park, 2018).

Robots perform the repetitive, hard, dirty, and dangerous tasks that employees prefer to avoid. From the perspective of the hotels, robots transform their business processes (Ivanov, 2019); operations, marketing (Murphy et al., 2019); human resource and financial management (Tung and Law, 2017; Tung and Au, 2018; Qiu et al., 2019), improve productivity, save employees' time, and increase revenues (Ivanov, 2019). Robots are still quite expensive, although their prices are dropping significantly in recent years, and there are attempts to make affordable robots for hospitality and hotels (Kelly et al., 2017; Webster and Ivanov, 2020).

Robots may be found and supporting the different departments of hotels serving guests (Rajesh, 2015). The hotel features robotic front desk agents, porters, inroom, vacuum cleaners, and a robotic arm operating the luggage storage room (Markoff, 2014; Murphy et al., 2019).

Also, robot can call the guest room to serve and deliver requested items to the guest's (Hilton 2016). Robot can communicate and serving the hotel guests and providing suggestions for nearby attractions and activities; can learn every interaction with guests. Even though SART have already reached different hotel departments, adoption of these technologies is still low. Therefore, in the future the hotels industry may observe higher penetration of such technologies (Ivanov et al., 2018).

Service automation through self-service and robotic technologies offers opportunities for reduced labor costs, and increased efficiency of hotel operations. Moreover, as a rare and innovative technology, robots may wow hotel guests and stimulate guest delight (Kuo, 2017).

The search is applied in the hotels of many countries of the world and some Arab countries. Research in service robots and service automation in hotels is yet to take off. Future research needs to investigate the economic fundamentals of service automation and adoption of robots by hotel; evaluate guests', employees' and managers' perception of service robots and service automation; assess the impact of robots, artificial intelligence and service automation on service quality, hotels' performance; investigate into the ethical issues of the use of service robots and service automation in hotels (Sorrells, 2013; Ivanov, 2019).

\section{Services Supported by the Framework}

Investigate possible applications of this pervasive computing framework in the hotels industry. Applicant services such as: self-check-in, identity recognition, concierge, in-room resource access, ambience adjustment, service access, and personalization, and contactless payment, information access, tracking children via 
RFID-enabled wristbands, smart waitresses and mini-bar, and performance management (Lorde et al., 2011; Kelly et al., 2017; Kim and Kim, 2018).

Furthermore, Self-Check-in is the process where a guest selects his room on his own through his own mobile device, for the check-in service, it establishes a connection to the server for updating room availability, and assigning the most suitable room to the guest (Trejos, 2015; Ivanov et al., 2018). Also, to identity recognition system which identifies the guests and their access permissions (Ngaiet al 2008; López et al., 2013; Rodriguez-Lizundia et al., 2015).

Moreover, In-room resource access system that intelligently adjusts comfortable temperature and the air conditioner off when no one is in the room (López et al., 2013, Kim and Qu, 2014). In-room ambience adjustment is provided by smart walls which are inherently large displays (Lorde et al., 2011). Instead of calling the reception desk, service access by automatic voice recognition is used in the hotel for getting information regarding services such as breakfast/lunch time and menus, entertainment activities in the hotel (Ivanov et al., 2018).

Furthermore, Personalization is based on the past history of the guests and regarding the profile database. A created service is adjustment of room temperature to preferred levels (Tussyadiah et al., 2017). For the smart employees such waitress service uses the hand-held device to serve the guests (Tom Dieck et al., 2016).

Moreover, Contactless payment system is an automation service for in-hotel expenditures (Curtis, 2016); Information access; Tracking children is performed by using RFID-enabled wristbands; the information manager takes the information regarding the exact location of the children in the hotel (Oztaysi et al., 2009; Murphy et al., 2017B). Employee performance management is used to create measurable parameters for managing employees' performance (Ritzer, 2015).

Communication technologies play a decisive role in organizing life from the locale of the home in the coronavirus crisis. The intermediary spaces of public life, where we used to spend leisure time and transit times in cafés, restaurants, parks, nature, public transport, etc. emptied out, which created ghost towns and urban ghost spaces (Fuchs 2020; World Health Organization, 2020; $\left.2020^{\mathrm{b}}\right)$.

Create an information point on the hotel website and social networks to share pertinent and applicable links to helpful sources; Establish an interior communications network; Develop an external communication strategy, including communicating with social media and a proactive sales and marketing strategy; Develop scenario-based holding statements ; Trail news updates and inform guest ; Keep in mind that associates who are confident and instill confidence that guest health and safety are taken seriously (Lanz et al., 2020; World Health Organization, $\left.2020^{\mathrm{d}}\right)$.

\section{Consumer centric marketing $(\mathrm{CCM})$}

Consumer centric marketing (CCM)- can be defined as "the discipline of capturing and deploying guest insights to enhance marketing effectiveness and better serve those guests that are brand's best prospects" (Maney et al. , 2002). CCM Definition: 
This is a marketing tactic where businesses focus their marketing strategy around the consumer experience (Chavez et al., 2016). Hu man resources are the most important factor in the implementation of CCM because they are in direct contact with guests' desires, needs and expectations (Ivanovic et al., 2011).

Adopting a customer-centric marketing is not an easy task until now most of the hotels were using product-centric marketing strategy. It is possible to take its full benefits and gain a competitive advantage to satisfy guest' needs (Kearns, 2010; Gihan and Hany, 2015). Moreover, Customer-centric marketing is the most important characteristic in establishing a truly "digital-native" culture; Adopting digital culture means that they automatically become customer-centric hotels; The lack of adequate technologies to manage data is a great problem for hotels companies; if employees don't trained well and know how to deal with the available data, it is impossible to take full benefit of it (Kumar et al., 2016 ${ }^{\mathrm{A}+\mathrm{B}}$ ).

CRM tactic where businesses focus their marketing strategy around the consumer experience :Create a Personalized Experience and practice; Understand the customer; Identify the Needs of the customer; Involve the customer in the hotel Storytelling; Build a Long-Lasting Relationship with customer; continuing and nonstop Research; Empathy; Measure Development; Create Attractive Content; Be Consistent and Reliable; and Enhance the Customer experiment (Chavez et al., 2016).

\section{Benefits of the Proposed Framework}

SART systems provide increased CCM, Guest' Satisfaction, safety and prevent infections, and Employees' knowledge and productivity, decreased inventory costs and energy. Moreover, profit increases, competitive advantage and brand differentiation are achieved (Lorde et al., 2011; Murphy et al., 2017 ${ }^{\mathrm{B}}$; Ivanov, 2019). also, guest' satisfaction is the hotels goal, and is increased by reducing service times, employee performance, quality of service, profits, assisting find locations in the hotel by using the augmented reality applications, and by the smart mini-bar service. Furthermore, personalization, service innovation, competitive advantage, Guest' Satisfaction and safety (Gladstone, 2016; Kuo and Boger, 2016; Tussyadiah and Park, 2018).

Moreover, the in-room resource access service reduces the building energy expenses. The employee performance management and the smart-waitress service increase efficacy of the employees, and reduction cost. The self-check-in service eliminates the receptionist process; reduced cost and workload. The smart mini-bars provide fast service and automatic billing, reduce inventory levels and trigger automatic ordering. Thus, cost is reduced (Gökalp and Eren, 2013; Murphy, 2017A).

\section{Materials and methodology \\ Data collection}

A self-administered questionnaire include the employees' expectations about the SART as a tool to increase CCM and guest' satisfaction. The data was collected through the 3rd 2020 quarter "from July to September". 
The Sample Population: The study was conducted on a sample of 28 five star hotels Egyptian hotels because they are the five star hotels is the highest category of hotels. The chosen of the hotels were due to variety of the locations and availability and opening they are on operation in the area of Sharm El-Sheikh, Hurghada, and Cairo because they are the most working area in this time . The hotels samples are as follows in table (1).

\section{Table 1}

The Sample Population

\begin{tabular}{|c|l|c|}
\hline No. & \multicolumn{1}{|c|}{ Hotel name } & No. of rooms \\
\hline & Sharm El-Sheikh five star hotels & \\
\hline 1. & Four Seasons Resort Sharm El-Sheikh & 238 \\
\hline 2. & Hilton Sharm Dreams Resort & $394+$ time share \\
\hline 3. & Iberotel Palace Sharm El-Sheikh & 263 \\
\hline 4. & Jaz Mirable Beach Resort & 1001 \\
\hline 5. & Maritim Jolie Ville Golf and Resort & 418 \\
\hline 6. & Marriott Hotel Sharm El-Sheikh & 520 \\
\hline 7. & Savoy Hotel Sharm El-Sheikh & 790 \\
\hline 8. & Sheraton Sharm El Sheikh, Resort, Villas. & 847 \\
\hline 9. & Sonesta Beach Resort Sharm El-Sheikh & 520 \\
\hline 10. & Sunrise Select Island View Resort & 492 \\
\hline & Hurghada five star hotels & 546 \\
\hline 1. & DESSOLE PYRAMISA SAHL HASHISH HOTEL & 392 \\
\hline 2. & HILTON HURGHADA RESORT & 318 \\
\hline 3. & HURGHADA MARRIOTT BEACH RESORT & 167 \\
\hline 4. & JAZ MAKADI STAR RESORT and SPA & 878 \\
\hline 5. & PARADISE GOLDEN 5 RESORT & 719 \\
\hline 6. & SERENITY MAKADI HEIGHTS & 388 \\
\hline 7. & STEIGENBERGER ALDAU BEACH HOTEL & 530 \\
\hline 8. & SUNRISE MAMLOUK PALACE RESORT & \\
\hline & Cairo five star hotels & 1250 \\
\hline 1. & Cairo Marriott Hotel & 617 \\
\hline 2. & Conrad Cairo Hotel & 588 \\
\hline 3. & Fairmont Heliopolis Hotel & 296 \\
\hline 4. & Four Seasons Cairo Hotel & 715 \\
\hline 5. & Grand Nile Tower Cairo Hotel & 342 \\
\hline 6. & Ramses Hilton Hotel & 436 \\
\hline 7. & Semiramis Intercontinental Cairo & 409 \\
\hline 8. & Sheraton Cairo Hotel & \\
\hline 9. & Sofitel El Gezirah Hotel & \\
\hline 10. & Sonesta Hotel Tower \&Casino Cairo & \\
\hline & & \\
\hline
\end{tabular}

\section{Survey}

The field study accomplished through survey by personal visits, phone calls, social media networks, emails, and fax. A survey was carried out on (28 Egyptian five star hotels in 'Cairo, Hurghada, and Sharm El Sheikh to know which implement or use the SART. 
Questionnaires provide an efficient way of collecting a large amount of data from a sizable population of SART as a tool to increase guest. The questionnaire consists of four parts or dimension: The first dimension: the benefits of SART, the Second dimension: is the actual situation "reality", the third dimension: the predictable opportunities and threats, fourth dimension: Guest' Satisfaction and safety.

Pilot study was conducted in this study during June 2020. The aim of the pilot study was to find out SART as a tool to increase Guest' Satisfaction. Moreover, to ensure that the survey was well designed and easily understood by potential respondents, to examine the reliability and validity of the research tools as well as to develop and refine measure of the questions. Questionnaire was reviewed by some academic scholars to establish their appropriateness, clarity and to ease the understanding. Some alterations were suggested and then were implemented.

Questionnaire was then pre-tested in order to investigate the respondent's understanding of scale items and to identify also any issues that was complex or confusing in order to develop suitable scale items to ensure the validity and reliability of the research. For this determination, a questionnaire was distributed to a sample of managers, department managers and supervisors. A number of 35 forms were distributed to respondents who were asked to complete them.

The field study accomplished through survey by phone calls, social media networks, and emails. The target population for this study was carried out with senior managers was mainly conducted through a self-administered questionnaire on the Rooms division, F\&B and Sales and marketing departments' data collected by personal visits, phone calls, emails, fax. The questionnaire was focused on the management and supervisors' expectations about the knowledge management and its effect on staff in order evaluate the impact of Service Automation and Robotic Technologies (SART) to increase the guest satisfaction in Egyptian hotels.

The study was conducted from July 2020 to September 2020. 550 questionnaire forms were received only 442 completed forms were valid (80.36\% validate rate). The target population for this study was the hotel employees, supervisors, Departmental head and managers; moreover, questionnaires were conducted with personal visits, internet, and online hotel employees, supervisors, and managers.

Survey was carried out on SART as a Tool to increase Guest' Satisfaction and safety in Egypt. The questionnaire used to assess how SART as a tool to increase Guest' Satisfaction and safety in Egypt. The data collected from hotels were used declares a descriptive analysis of managers, supervisors and employees' questionnaire by using SPSS version 20.

\section{Study Instrument reliability}

For all scales, Cronbach's Alpha, the correlation coefficient was calculated to regulate the internal consistency of the scale. The Cronbach's Alpha reliability was computed, and the tests showed that the reliability coefficients for all the instruments were above 0.98 , which indicates that the instrument was reliable for being used. The Reliability coefficient is over 0.70 it is considered "strongly 
acceptable" in most social science situations. Cronbach alpha for all survey instruments as shown in the following table (2).

Table 2

Reliability Statistics

\begin{tabular}{|c|c|c|}
\hline Cronbach's Alpha & No. of Items & No of questionnaires \\
\hline .984 & 41 & 442 \\
\hline
\end{tabular}

\section{Results}

This part of the study included the results of the questionnaire forms distributed on the internet on Facebook, online Google drive, email, and personnel visits. To find out what are the managers, supervisors and employees' opinions regarding the role of SART as a Tool to Increase Guest' Satisfaction in the Egyptian hotels.

Statistical package of social sciences (SPSS) version 20.0 for windows was used to analyze and compute the collected data, except the open question. Frequencies and percentage distributions were used to shed the light on the role of SART in the development of Guest' Satisfaction and safety.

\section{Respondent's Demographics}

\section{Table 3}

The respondents according to demographic and career data $(\mathrm{n}=442)$

\begin{tabular}{|l|l|l|}
\hline Demographic data & No. & \% \\
\hline Gender & & \\
\hline Male & 402 & 91.0 \\
\hline Female & 40 & 9.0 \\
\hline Total & 442 & 100.0 \\
\hline Age & & \\
\hline From 18 to 28 & 40 & 9.0 \\
\hline Over 28 to 38 & 90 & 20.4 \\
\hline Over 38 to 48 & 150 & 33.9 \\
\hline Over 48 to 60 & 162 & 36.7 \\
\hline Total & 442 & 100.0 \\
\hline Education & & \\
\hline Below first degree & 120 & 27.1 \\
\hline Four years degree & 302 & 68.3 \\
\hline Postgraduate & 20 & 4.5 \\
\hline Total & 442 & 100.0 \\
\hline Experience & & \\
\hline Less than 5 year & 40 & 9.0 \\
\hline Between 5 and 10 years & 130 & 29.4 \\
\hline More than 10 to 15 years & 192 & 43.4 \\
\hline More than 15 years & 80 & 18.1 \\
\hline Total & 442 & 100.0 \\
\hline Position & & \\
\hline Employee "team member & 60 & 13.6 \\
\hline Supervisor Operational & 215 & 48.6 \\
\hline Departmental head & 139 & 31.4 \\
\hline & & continued \\
\hline I P a g e & & \\
\hline
\end{tabular}




\begin{tabular}{|l|l|l|}
\hline Manager & 28 & 6.3 \\
\hline Total & 442 & 100.0 \\
\hline Department & & \\
\hline Sales and Marketing & 52 & 11.8 \\
\hline Information technology (IT) & 68 & 15.4 \\
\hline Rooms division & 200 & 45.2 \\
\hline Food and beverage & 82 & 18.6 \\
\hline Others & 40 & 9.0 \\
\hline Total & 442 & 100.0 \\
\hline
\end{tabular}

The distribution of the respondents according to demographic data $(n=442)$ indicated that regarding the gender most of the respondents were Men; the percentage of respondents was $36.7 \%$ at the age of over 48 to 60years and 33.9 Over 38 to 48 years. A Four years degree has a great percentage of $68.3 \%$ of all respondents. Regarding the experience, most of the respondents were More than 10 to 15 years by the percentage of $43.4 \%$. Concerning the position, most of the respondents were supervisor operational by the percentage of $48.6 \%$ and followed by departmental head by the percentage of $31.4 \%$. In accordance with department, most of the respondents were Rooms division by the percentage of $45.2 \%$. The results indicate that most of the respondents are well educated, experience and able to apply SART to assuring and increasing Guest' Satisfaction as shown in table (3).

\section{Evaluating the employees' vision regarding the SART in the Egyptian hotels: Rendering the first dimension: the benefits the results showed that:}

In accordance to the first acceptance average level was Applying the SART in the Egyptian hotels positively influence the Guest' Satisfaction. With (99.46 \%) average, mean (497) and Std (0.16). results show that the importance of Applying the SART to increase Guest' Satisfaction. Concerning the second level agrees average was $(98.91 \%)$ regarding agree with that Adapting appropriate system of SART efficiency positively influences CCM. with mean (4.95) and Std (0.23). this indicate the importance of the SART for CCM to enhance guests' satisfaction. Regarding SART positively increase the level of services process. Achieved the third level by average acceptance $(98.73 \%)$ with a mean (4.94) and Std (0.24). this show the role of SART in increase the level of services process to enhance guests' satisfaction. Regarding both of the Adapting appropriate system of SART efficiency positively influences the hotel to determine guests' expectations and needs achieved the fourth level by average acceptance (98.19\%) with mean (4.91) and Std (0.29). results show the role of SART in safety and infections prevention as well as read guests' expectations and needs. In the fifth rank was that SART positively increase customer' orientation, by a percentage of $(97.83 \%)$ as agree average, with a mean (4.89) and Std (0.31). results show the impact of SART in increase customer' orientation to enhance guests' satisfaction.

In accordance to the sixth acceptance average levels were SART affect employees' satisfaction. With $(97.65 \%)$ average, mean (4.88) and Std (0.32). results show that the importance of the SART to increase employees' satisfaction. Concerning the seventh level agrees average was $(97.10 \%)$ regarding agree with that SART support the business revenue and profit increases. with mean (4.86) and Std (0.35). this 
indicate the importance of the SART for support the business revenue and profit increases. Regarding role of SART to increase Internet based communication tools to enhance guests' satisfaction were Achieved the eighth level by average acceptance $(96.56 \%)$ with a mean (4.83) and Std (0.38). this show the role of SART in increase Internet based communication tools to enhance guests' satisfaction. Regarding all of the Using SART play a major role in influencing guest choice for the hotel; and the SART systems provide increased guest 'retention; and Adapting appropriate system of SART positively influences Loyalty programs achieved the ninth level by average acceptance $(96.38 \%)$ with mean (4.82) and Std (0.39). results show the role of SART in influencing guest choice for the hotel and increased guest 'retention. In accordance to the tenth acceptance average level was adapting appropriate system of SART positively influences Employees' knowledge and efficiency With (95.66\%) average, mean (4.78) and Std (0.41). results show that the importance of the SART to increase positively Employees' knowledge and efficiency These results agreed with (Lorde et al., 2011; Gökalp and Eren, 2013; Trejos, 2015; Gladstone, 2016; Kelly et al., 2017; Kim and Kim, 2018; Tussyadiah and Park, 2018; Ivanov, 2019; Murphy et al., 2019) .

\section{According to the second dimension: the strangeness and weakness points "reality" (second dimension) the results showed that:}

Table (4) lists the mean scores of the second dimension: reality (Strengths and Weaknesses, the results showed that most of the samples $(98.37 \%)$ were SART newly emerging technologies in hospitality services, with a mean (4.92) and std. deviation (0.27). Item no. 2, was aimed to know if There is a relationship between your expectations, satisfaction and SART, results showed that most of the sample (98.01\%) was agreed with that. results indicates that, There is a relationship between SART and Guest' Satisfaction , with a mean (4.90) and std. deviation (0.30). Smart mini-bars provide fast service and automatic billing, results showed that $(87.78 \%)$ of the respondents were agreed about these benefits, indicated the hotels care about fast and automatic service and billing, SD (4.39) and m (0.49). The hotels exploit their services using different SART. Achieved the fourth level by average acceptance $(74.48 \%)$ with mean (3.72) and Std (0. 0.65). results show that hotel using different service Automation Technologies and CCM apps and practices. In the fifth rank was that Hotel ensures that SART improve service performance and increase your satisfaction, by a percentage of $(76.47 \%)$ as agree average, with a mean (3.82) and Std (0.69). results show that Hotel ensures that SART improve service performance and increase Guest' Satisfaction. These results agreed with (Tung and Au, 2018; Ivanov, 2019; Webster and Ivanov, 2020).

On the other side, in the last ranking position (the sixteenth) was In-room resource access system that intelligently adjusts temperature settings based on personal preferences and the air conditioner off when no one is in the room, by percentage (56.20), with a mean (2.81) and Std (0.55); results indicate that Egyptian hotels need more care regarding applied SART. In accordance, SART are well applied in Egyptian hotels, by percentage (58.37), with a mean (2.92) and Std (0.74); results indicate that Egyptian hotels need more care regarding applied SART. Regarding 
the $14^{\text {th }}$ position is In-room atmosphere adjustment inherently large displays. By a percentage of (59.82\%) as agree average, with a mean (2.99) and Std (0.56); this indicates that the hotels need more care regarding In-room ambience. Concerning the $13^{\text {th }}$ level agrees average was $(60.77 \%)$ regarding Identity recognition system which identifies the guests and their access permissions. With mean (3.04) and Std (0.70). These results agreed with (Kelly et al., 2017; Kim and Kim, 2018; Tussyadiah and Park, 2018). 


\begin{tabular}{|c|c|c|c|c|c|c|c|c|c|c|c|c|c|c|c|c|c|}
\hline \multirow{3}{*}{$\dot{\mathrm{z}}$} & \multicolumn{17}{|c|}{$\begin{array}{l}\text { Table } 4 \\
\text { Evaluating the employees' vision regarding the SART in the Egyptian hotels }\end{array}$} \\
\hline & \multirow[t]{2}{*}{$\frac{\pi}{8}$} & \multirow[t]{2}{*}{ Factor } & \multicolumn{2}{|c|}{ 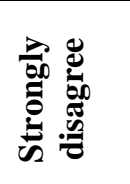 } & \multicolumn{2}{|l|}{ 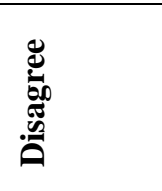 } & \multicolumn{2}{|l|}{ } & \multicolumn{2}{|l|}{ 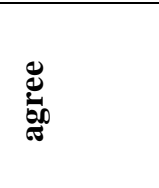 } & \multicolumn{2}{|c|}{ 常 } & \multicolumn{2}{|c|}{ Mean } & \multirow{2}{*}{ 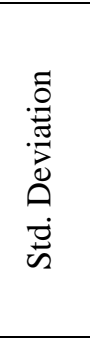 } & \multirow{2}{*}{ 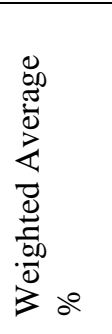 } & \multirow[t]{2}{*}{ 茞 } \\
\hline & & & 禺 & o & 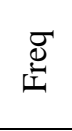 & de & 总 & o & 总 & bo & 岛 & b & 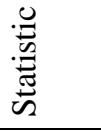 & 它冝 & & & \\
\hline & & \multicolumn{16}{|l|}{ The first dimension: the benefits } \\
\hline 1. & a1 & $\begin{array}{l}\text { Applying the SART in the Egyptian hotels positively } \\
\text { influences the guest' satisfaction. }\end{array}$ & 0 & 0 & 0 & 0 & 0 & 0 & 12 & 3 & 430 & 97 & 4.97 & 0.01 & 0.16 & 99.46 & 1 \\
\hline 2. & $\mathrm{a} 2$ & $\begin{array}{l}\text { Adapting appropriate system of SART positively influences } \\
\text { Employees' knowledge and efficiency. }\end{array}$ & 0 & 0 & 0 & 0 & 0 & 0 & 96 & 22 & 346 & 78 & 4.78 & 0.02 & 0.41 & 95.66 & 10 \\
\hline 3. & a3 & $\begin{array}{l}\text { Using SART play a major role in influencing guest choice } \\
\text { for the hotel. }\end{array}$ & 0 & 0 & 0 & 0 & 0 & 0 & 80 & 18 & 362 & 82 & 4.82 & 0.02 & 0.39 & 96.38 & $9 *$ \\
\hline 4. & a4 & SART systems provide increased guest' retention. & 0 & 0 & 0 & 0 & 0 & 0 & 80 & 18 & 362 & 82 & 4.82 & 0.02 & 0.39 & 96.38 & $9 *$ \\
\hline 5. & a5 & $\begin{array}{l}\text { Adapting appropriate system of SART efficiency positively } \\
\text { influences assuring safety and infections prevention. }\end{array}$ & 0 & 0 & 0 & 0 & 0 & 0 & 40 & 9 & 402 & 91 & 4.91 & 0.01 & 0.29 & 98.19 & $4 *$ \\
\hline 6. & $\mathrm{a} 6$ & SART support the business revenue and profit increases. & 0 & 0 & 0 & 0 & 0 & 0 & 64 & 15 & 378 & 86 & 4.86 & 0.02 & 0.35 & 97.10 & 7 \\
\hline 7. & a7 & $\begin{array}{l}\text { SART to increase Internet based communication tools to } \\
\text { enhance guests' satisfaction. }\end{array}$ & 0 & 0 & 0 & 0 & 0 & 0 & 76 & 17 & 366 & 83 & 4.83 & 0.02 & 0.38 & 96.56 & 8 \\
\hline 8. & a8 & $\begin{array}{l}\text { Adapting appropriate system of SART positively influences } \\
\text { loyalty programs. }\end{array}$ & 0 & 0 & 0 & 0 & 0 & 0 & 80 & 18 & 362 & 82 & 4.82 & 0.02 & 0.39 & 96.38 & $9 *$ \\
\hline 9. & a9 & SART positively increase the level of services process. & 0 & 0 & 0 & 0 & 0 & 0 & 28 & 6 & 414 & 94 & 4.94 & 0.01 & 0.24 & 98.73 & 3 \\
\hline 10. & a10 & $\begin{array}{l}\text { Adapting appropriate system of SART efficiency positively } \\
\text { influences CCM. }\end{array}$ & 0 & 0 & 0 & 0 & 0 & 0 & 24 & 5 & 418 & 95 & 4.95 & 0.01 & 0.23 & 98.91 & 2 \\
\hline 11. & a11 & SART positively increase customer' orientation. & 0 & 0 & 0 & 0 & 0 & 0 & 48 & 11 & 394 & 89 & 4.89 & 0.01 & 0.31 & 97.83 & 5 \\
\hline 12. & a12 & $\begin{array}{l}\text { SART helps the hotel to determine guests' expectations } \\
\text { and needs. }\end{array}$ & 0 & 0 & 0 & 0 & 0 & 0 & 40 & 9 & 402 & 91 & 4.91 & 0.01 & 0.29 & 98.19 & $4 *$ \\
\hline 13. & a13 & SART affect employees' satisfaction. & 0 & 0 & 0 & 0 & 0 & 0 & 52 & 12 & 390 & 88 & 4.88 & 0.02 & 0.32 & 97.65 & 6 \\
\hline
\end{tabular}




\begin{tabular}{|c|c|c|c|c|c|c|c|c|c|c|c|c|c|c|c|c|c|}
\hline \multirow{3}{*}{$\dot{z}$} & \multicolumn{17}{|c|}{$\begin{array}{l}\text { Table } 4 \\
\text { Evaluating the employees' vision regarding the SART in the Egyptian hotels }\end{array}$} \\
\hline & \multirow[t]{2}{*}{$\frac{8}{0}$} & \multirow[t]{2}{*}{ Factor } & \multicolumn{2}{|c|}{ 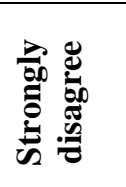 } & \multicolumn{2}{|l|}{ 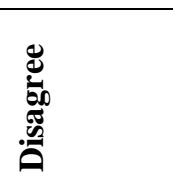 } & \multicolumn{2}{|l|}{ } & \multicolumn{2}{|l|}{ 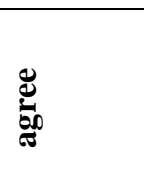 } & \multicolumn{2}{|c|}{ 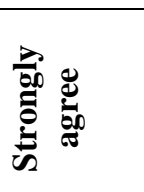 } & \multicolumn{2}{|c|}{ Mean } & \multirow{2}{*}{ 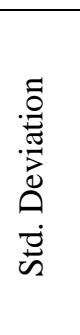 } & \multirow{2}{*}{ 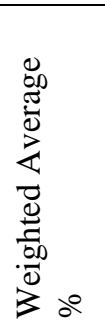 } & \multirow[t]{2}{*}{ 卷 } \\
\hline & & & $\underset{\mathscr{D}}{\mathscr{D}}$ & $b^{\circ}$ & $\underset{\mathscr{D}}{\mathscr{D}}$ & $b^{\circ}$ & $\underset{\mathscr{D}}{\mathscr{D}}$ & bo & $\underset{D}{\mathscr{D}}$ & $b^{\circ}$ & $\underset{\mathscr{D}}{\mathscr{D}}$ & $\Delta^{0}$ & 莺 & 离 & & & \\
\hline & & The second dimension: reality (Strengths and Weaknesses & & & & & & & & & & & & & & & \\
\hline 1. & b1 & SART applications applied in Egypt & 0 & 0 & 0 & 0 & 170 & 39 & 228 & 52 & 44 & 10 & 3.71 & 0.03 & 0.64 & 74.30 & $7 *$ \\
\hline 2. & b2 & SART are well applied in Egyptian hotels. & 0 & 0 & 140 & 32 & 198 & 45 & 104 & 24 & 0 & 0 & 2.92 & 0.04 & 0.74 & 58.37 & 15 \\
\hline 3. & b3 & Hotels management in Egypt directs good budgets to SART. & 0 & 0 & 100 & 23 & 215 & 49 & 83 & 19 & 44 & 10 & 3.16 & 0.04 & 0.89 & 63.21 & 11 \\
\hline 4. & $\mathrm{~b} 4$ & $\begin{array}{l}\text { Management is very sensitive to the service automation } \\
\text { technologies that were already going on within the company } \\
\text { and seek mean to support them. }\end{array}$ & 0 & 0 & 0 & 0 & 315 & 71 & 127 & 29 & 0 & 0 & 3.29 & 0.02 & 0.45 & 65.75 & $\begin{array}{r}10 \\
*\end{array}$ \\
\hline 5. & b5 & $\begin{array}{l}\text { Self-Check-in process where a guest selects the room on } \\
\text { his own through his own mobile device or the hotel kiosk. }\end{array}$ & 0 & 0 & 0 & 0 & 160 & 36 & 226 & 51 & 56 & 13 & 3.76 & 0.03 & 0.66 & 75.29 & 6 \\
\hline 6. & b6 & $\begin{array}{l}\text { Identity recognition system which identifies the guests and } \\
\text { access permissions. }\end{array}$ & 0 & 0 & 100 & 23 & 225 & 51 & 117 & 27 & 0 & 0 & 3.04 & 0.03 & 0.70 & 60.77 & 13 \\
\hline 7. & b7 & $\begin{array}{l}\text { In-room resource access system that adjusts comfortable } \\
\text { temperature. }\end{array}$ & 0 & 0 & 116 & 26 & 294 & 67 & 32 & 7 & 0 & 0 & 2.81 & 0.03 & 0.55 & 56.20 & 16 \\
\hline 8. & $\mathrm{~b} 8$ & $\begin{array}{l}\text { In-room ambience adjustment is provided by smart walls } \\
\text { which are inherently large displays. }\end{array}$ & 0 & 0 & 72 & 16 & 302 & 68 & 68 & 15 & 0 & 0 & 2.99 & 0.03 & 0.56 & 59.82 & 14 \\
\hline 9. & b9 & Automatic voice recognition for service access. & 0 & 0 & 44 & 10 & 310 & 70 & 88 & 20 & 0 & 0 & 3.10 & 0.03 & 0.54 & 61.99 & 12 \\
\hline 10. & b10 & $\begin{array}{l}\text { Personalization based on the profile database record the } \\
\text { past history of the guests regarding climate, mini-bar usage, } \\
\text { and TV. }\end{array}$ & 0 & 0 & 44 & 10 & 221 & 50 & 177 & 40 & 0 & 0 & 3.30 & 0.03 & 0.64 & 66.02 & 9 \\
\hline 11. & b11 & $\begin{array}{l}\text { For the smart employees such as waitress service by using } \\
\text { hand-held device for recommending menu items to the } \\
\text { guests. }\end{array}$ & 0 & 0 & 84 & 19 & 146 & 33 & 212 & 48 & 0 & 0 & 3.29 & 0.04 & 0.77 & 65.79 & $\begin{array}{r}10 \\
*\end{array}$ \\
\hline 12. & b12 & Contactless automation payment system. & 0 & 0 & 0 & 0 & 170 & 39 & 228 & 52 & 44 & 10 & 3.71 & 0.03 & 0.64 & 74.30 & $7^{*}$ \\
\hline 13. & b13 & Tracking children by using RFID. & 0 & 0 & 40 & 9 & 155 & 35 & 247 & 56 & 0 & 0 & 3.47 & 0.03 & 0.66 & 69.37 & 8 \\
\hline
\end{tabular}

143 | P a g e 


\begin{tabular}{|c|c|c|c|c|c|c|c|c|c|c|c|c|c|c|c|c|c|}
\hline \multirow{3}{*}{$\dot{0}$} & \multicolumn{17}{|c|}{$\begin{array}{l}\text { Table } 4 \\
\text { Evaluating the employees' vision regarding the SART in the Egyptian hotels }\end{array}$} \\
\hline & \multirow[t]{2}{*}{$\frac{0}{0}$} & \multirow[t]{2}{*}{ Factor } & \multicolumn{2}{|c|}{ 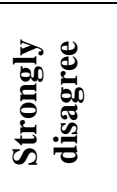 } & \multicolumn{2}{|l|}{ 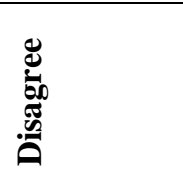 } & \multicolumn{2}{|l|}{ } & \multicolumn{2}{|l|}{ 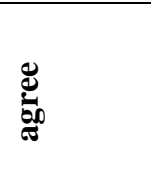 } & \multicolumn{2}{|c|}{ 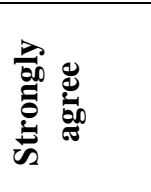 } & \multicolumn{2}{|c|}{ Mean } & \multirow{2}{*}{ 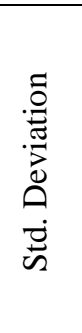 } & \multirow{2}{*}{ 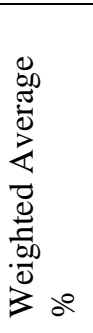 } & \multirow[t]{2}{*}{ 光 } \\
\hline & & & 总 & $s^{\circ}$ & 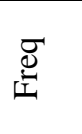 & so & 巳্் & de & Ð્乌 & $b^{e}$ & 巳্ৰ & $b^{e}$ & 葋 & 总 & & & \\
\hline 14. & b14 & Smart mini-bars provide service and automatic billing. & 0 & 0 & 0 & 0 & 0 & 0 & 270 & 61 & 172 & 39 & 4.39 & 0.02 & 0.49 & 87.78 & 3 \\
\hline 15. & b15 & $\begin{array}{l}\text { Hotel ensures that SART improve service performance and } \\
\text { increase your satisfaction. }\end{array}$ & 0 & 0 & 0 & 0 & 150 & 34 & 220 & 50 & 72 & 16 & 3.82 & 0.03 & 0.69 & 76.47 & 4 \\
\hline 16. & b16 & The hotel exploits their services using different SART. & 0 & 0 & 0 & 0 & 170 & 39 & 224 & 51 & 48 & 11 & 3.72 & 0.03 & 0.65 & 74.48 & 5 \\
\hline 17. & b17 & $\begin{array}{l}\text { There is a relationship between your expectations, } \\
\text { satisfaction and SART. }\end{array}$ & 0 & 0 & 0 & 0 & 0 & 0 & 44 & 10 & 398 & 90 & 4.90 & 0.01 & 0.30 & 98.01 & 2 \\
\hline \multirow[t]{2}{*}{18.} & b18 & SART newly emerging technologies in hospitality services & 0 & 0 & 0 & 0 & 0 & 0 & 36 & 8 & 406 & 92 & 4.92 & 0.01 & 0.27 & 98.37 & 1 \\
\hline & & \multicolumn{16}{|l|}{ The third dimension: the predictable opportunities and threats } \\
\hline 1. & $\mathrm{c} 1$ & Applying SART still expensive. & 0 & 0 & 0 & 0 & 36 & 8 & 134 & 30 & 272 & 62 & 4.53 & 0.03 & 0.64 & 90.68 & 3 \\
\hline 2. & $\mathrm{c} 2$ & SART need training. & 0 & 0 & 0 & 0 & 0 & 0 & 120 & 27 & 322 & 73 & 4.73 & 0.02 & 0.45 & 94.57 & 2 \\
\hline 3. & $\mathrm{c} 3$ & SART need high investment. & 0 & 0 & 0 & 0 & 36 & 8 & 279 & 63 & 127 & 29 & 4.21 & 0.03 & 0.57 & 84.12 & 4 \\
\hline 4. & $\mathrm{c} 4$ & SART need continuous improvement in Egypt. & 0 & 0 & 0 & 0 & 140 & 32 & 218 & 49 & 84 & 19 & 3.87 & 0.03 & 0.70 & 77.47 & 5 \\
\hline 5. & $\mathrm{c} 5$ & SART are fast changing. & 0 & 0 & 0 & 0 & 0 & 0 & 80 & 18 & 362 & 82 & 4.82 & 0.02 & 0.39 & 96.38 & 1 \\
\hline 6. & c6 & $\begin{array}{l}\text { Egyptian hotels systems are adequately preparing us for } \\
\text { SART. }\end{array}$ & 0 & 0 & 145 & 33 & 209 & 47 & 88 & 20 & 0 & 0 & 2.87 & 0.03 & 0.72 & 57.42 & 9 \\
\hline 7. & $\mathrm{c} 7$ & Egyptian hotels are well aware of the effect of SART. & 0 & 0 & 80 & 18 & 230 & 52 & 132 & 30 & 0 & 0 & 3.12 & 0.03 & 0.68 & 62.35 & $8 *$ \\
\hline 8. & $\mathrm{c} 8$ & $\begin{array}{l}\text { Egyptian hotels are effectively implementing adequate } \\
\text { SART. }\end{array}$ & 0 & 0 & 36 & 8 & 219 & 50 & 187 & 42 & 0 & 0 & 3.34 & 0.03 & 0.62 & 66.83 & 7 \\
\hline 9. & c9 & $\begin{array}{l}\text { Employees show that they have good awareness level } \\
\text { regarding SART. }\end{array}$ & 0 & 0 & 0 & 0 & 250 & 57 & 160 & 36 & 32 & 7 & 3.51 & 0.03 & 0.63 & 70.14 & 6 \\
\hline 10. & $\mathrm{c} 10$ & The activities SART are consistent with Egyptian hotels. & 0 & 0 & 80 & 18 & 230 & 52 & 132 & 30 & 0 & 0 & 3.12 & 0.03 & 0.68 & 62.35 & 8* \\
\hline
\end{tabular}


According to the third dimension: the predictable opportunities and threats the results in table (4) showed that in accordance to the $1^{\text {st }}$ acceptance average level was that the SART are fast changing, with (96.38 \%) average, mean (4.82) and Std (0.39); this indicated that SART need continues awareness and developments. In the $2^{\text {nd }}$ position was that SART need training, by a percentage of $(94.57 \%)$ as agree with average, with a mean (4.73) and Std (0.45); training needs to be continuously. Regarding the $3^{\text {rd }}$ priority to the SART still expensive, with agree average level (90.68 \%), mean was (4.53) and Std (0.64); this indicates that the SART still expensive. Dealing with the $4^{\text {th }}$ importance with $(84.12 \%)$ as an acceptance average for SART need high investment, with a mean (4.21) and Std (0.57); this indicates that SART need high investment. Concerning the $5^{\text {th }}$ agree level were SART need continuous improvement in Egypt, by average (77.47 \%), with Std (0.70) and mean (3.87). These results agreed with (Tussyadiah and Park, 2018; Tung and Au, 2018).

On the other side, the last $9^{\text {th }}$ acceptance average level was that Egyptian hotels systems are adequately preparing us for SART, by percentage (57.42), with a mean (2.87) and Std (0.72); this indicates that the hotels need more care regarding the adequate systems preparing. Egyptian hotels are well aware of the effect of SART. And the activities SART are consistent with Egyptian hotels. Were in the $8^{\text {th }}$ efficiency average by the percentage of (62.35\%), with a mean (3.12) and Std (0. 0.68); this indicates that hotels need to consistent with and improve the awareness about the effect of SART. Regarding the $7^{\text {th }}$ agree position where those Egyptian hotels are effectively implement adequate SART, by a percentage of $(66.83 \%)$ with a mean (3.34) and Std (0.62); this indicates that Egyptian hotels need more care regarding the effectively implement of adequate SART. In the $6^{\text {th }}$ position, Employees show that they have good awareness level regarding SART, by a percentage of $(70.14 \%)$ as agree average, with a mean (3.51) and Std (0.63); this indicates that hotels need more care regarding improving employees awareness regarding SART. These results agreed with (Kuo and Boger, 2016; Murphy, 2017 ${ }^{\mathrm{A}}$ Qiu et al., 2019).

\section{Respondents' opinion regarding to SART as a tool to increase guest' satisfaction in the Egyptian hotels}

The following table illustrates the means, standard deviations and ranking of the factors clarifying the respondents' opinion regarding the SWOT strategic planning analysis of SART as a tool to increase Guest' Satisfaction in the Egyptian hotels.

Results showed that the mean scores of the respondents were as following: the first dimension the scale and application possibility of the benefits of SART by mean 4.87 and SD 0.27; the second dimension: reality (Strengths and Weaknesses) by mean 3.57 from and SD 0.52. The third dimension: the predictable opportunities and threats by mean 3.81 and SD 0.53. As shown in table (5). 


\section{Table 5}

Descriptive analysis of the respondents' opinions according to SART as a Tool to Increase Guest' Satisfaction $(n=442)$

\begin{tabular}{|l|l|c|c|c|}
\hline \multirow{2}{*}{ No. } & \multicolumn{1}{|c|}{ Dimension } & \multicolumn{2}{|c|}{ Mean } & $\begin{array}{c}\text { Std. } \\
\text { Deviation }\end{array}$ \\
\cline { 3 - 5 } & & Statistic & Std. Error & Statistic \\
\hline TotalA & The first dimension: the benefits & 4.875 & 0.013 & 0.279 \\
\hline TotalB & $\begin{array}{l}\text { The second dimension: reality (Strengths } \\
\text { and Weaknesses) }\end{array}$ & 3.573 & 0.025 & 0.523 \\
\hline TotalC & $\begin{array}{l}\text { The third dimension: the predictable } \\
\text { opportunities and threats }\end{array}$ & 3.812 & 0.025 & 0.535 \\
\hline
\end{tabular}

\section{Hypotheses of the study:}

Regarding, H1: There is a significant impact of applying SART in the development on the main variables of the study ( Guest' Satisfaction ; Employees' knowledge; safety and infections prevention; CCM), One-Sample Test ( $\mathrm{T}$ - test) in table (6) used to compare means to show the values differences regarding the extent of the impact of applying SART in the development on the main variables of the study (Service automation and robotic; Guest' Satisfaction ; Employees' knowledge and efficiency; safety and infections prevention such; CCM).

Moreover, to apply one-sample T-test, the value (a1 and a10) were suggested because they were a suitable value that referred to the highest levels were a1: Guest' Satisfaction. with Mean 4.97; Std. Deviation 0.16; T value -3.508-; Mean Difference -.02715- ; and Sig. (2-tailed) was 0.000 . Followed by a10: CCM with Mean 4.94; Std. Deviation 0 .22; T value -5.032- ; Mean Difference -.05430- ; and Sig. (2-tailed) were 0.000 . The results showed that the p-value were definitely less than $.05(0.00)$. So, the null hypothesis was rejected and the first hypotheses of the research were valid. In the other word, there are no differences with a statistical significance between Guest' Satisfaction and CCM of service automation and robotic at the Egyptian hotels. These results assured the H1: There is a significant impact of applying SART in the development on the main variables of the study.

\section{Table 6}

One-Sample Test ( $\mathrm{T}$ - test) used to compare means

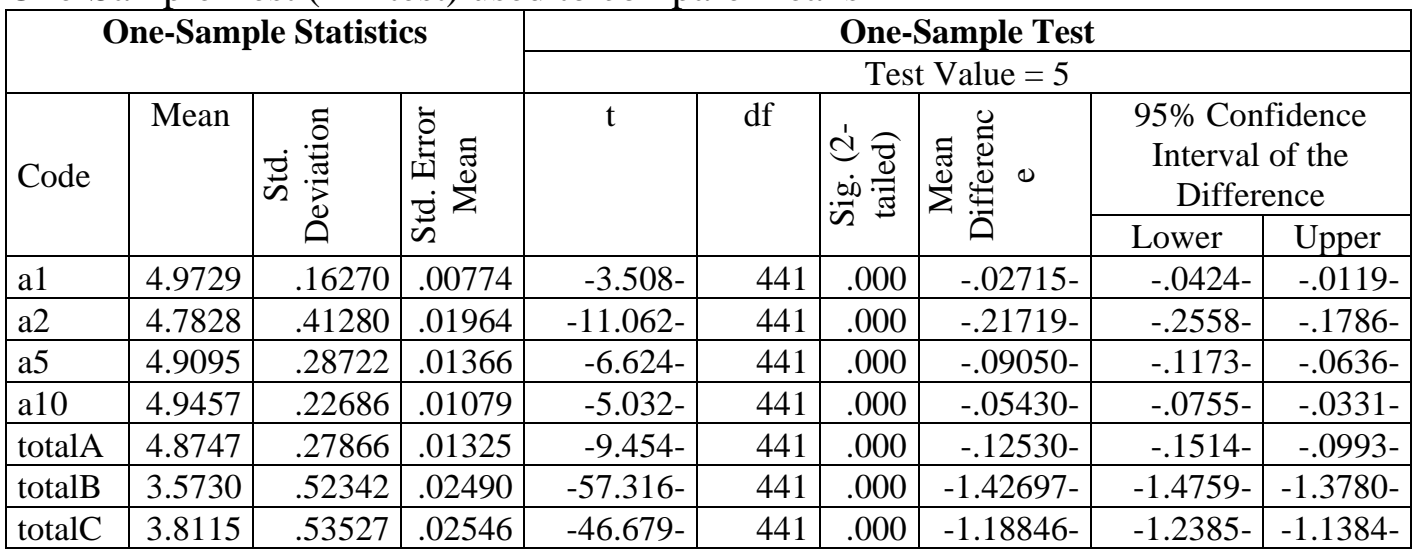


Nonparametric tests regarding independent samples H1: There is a significant impact difference of applying SART in the development on the main variables of the study (Guest' Satisfaction ; Employees' knowledge and efficiency; safety and infections prevention; CCM). Results showed that T-test value was significant at $(0.00)$ in each dimension this means that is revealed a statistically significant difference between the dimensions as shown in table 7.

On other words regarding the role of SART on comparing the (Guest' Satisfaction, Employees' knowledge and efficiency, safety and infections prevention, and CCM) Paired Samples Test assuring H1 through that: H1A: Applying the SART in the Egyptian hotels positively influences the Guest' Satisfaction, the Paired Samples Test were wit t value (-8.680-), and Sig. (2-tailed) (0 .000). Moreover, Paired Samples Correlations was with Correlation (0.525), and Sig. (0.000).

H1B: Adapting appropriate system of SART positively influences Employees' knowledge and efficiency, the Paired Samples Test were wit $t$ value (8.518), and Sig. (2-tailed) (0 .000). Moreover, Paired Samples Correlations was with Correlation (0.855), and Sig. (0.000). H1C: Using SART positively influences safety and infections prevention, the Paired Samples Test were wit t value (-5.049-), and Sig. (2tailed) (0 .000). Moreover, Paired Samples Correlations was with Correlation (0.869), and Sig. (0.000). H1D: Using SART positively influences CCM, the Paired Samples Test were wit t value (-7.648-), and Sig. (2-tailed) (0 .000). Moreover, Paired Samples Correlations was with Correlation (0.720), and Sig. (0.000).

\section{Table 7}

Paired Samples T-Test of the variables compared to each other (N: 442).

\begin{tabular}{|c|c|c|c|c|c|c|c|c|}
\hline & Paired Samples Statis & ics & & & $\begin{array}{r}\text { Pai } \\
\text { Sampl }\end{array}$ & Test & $\begin{array}{r}\mathrm{P} \\
\mathrm{Sa} \\
\mathrm{Corr}\end{array}$ & $\begin{array}{l}\text { ired } \\
\text { nples } \\
\text { lations }\end{array}$ \\
\hline & & Mean & 通 & 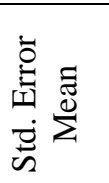 & $\mathrm{t}$ & $\begin{array}{c}\text { Sig. } \\
(2- \\
\text { tailed) }\end{array}$ & 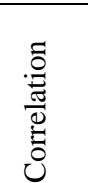 & Sig. \\
\hline Pair 1 & $\begin{array}{l}\text { TotalA: The first dimension: the } \\
\text { benefits. }\end{array}$ & 4.8747 & .27866 & .01325 & $-8.680-$ & .000 & .525 & .000 \\
\hline & a1: Guest' Satisfaction. & 4.9729 & .16270 & .00774 & & & & \\
\hline Pair 2 & $\begin{array}{l}\text { TotalB: The second dimension: } \\
\text { reality (Strengths and Weaknesses) }\end{array}$ & 3.5730 & .52342 & .02490 & $-58.729-$ & .000 & .290 & .000 \\
\hline & a1: Guest' Satisfaction. & 4.9729 & .16270 & .00774 & & & & \\
\hline Pair 3 & $\begin{array}{l}\text { TotalC: The third dimension: the } \\
\text { predictable opportunities and threats. }\end{array}$ & 3.8115 & .53527 & .02546 & $-48.074-$ & .000 & .316 & .000 \\
\hline & a1: Guest' Satisfaction. & 4.9729 & .16270 & .00774 & & & & \\
\hline Pair 4 & $\begin{array}{l}\text { TotalA: The first dimension: the } \\
\text { benefits. }\end{array}$ & 4.8747 & .27866 & .01325 & 8.518 & .000 & .855 & .000 \\
\hline & $\begin{array}{l}\text { a2: Employees' knowledge and } \\
\text { efficiency }\end{array}$ & 4.7828 & .41280 & .01964 & & & & \\
\hline Pair 5 & $\begin{array}{l}\text { TotalB: The second dimension: } \\
\text { reality (Strengths and Weaknesses) }\end{array}$ & 3.5730 & .52342 & 02490 & -71.267- & .000 & .734 & .000 \\
\hline & $\begin{array}{l}\text { a2: Employees' knowledge and } \\
\text { efficiency }\end{array}$ & 4.7828 & .41280 & .01964 & & & & \\
\hline & 10 & & & & & & col & lued \\
\hline
\end{tabular}




\begin{tabular}{|c|c|c|c|c|c|c|c|c|}
\hline \multirow[t]{2}{*}{ Pair 6} & $\begin{array}{l}\text { TotalC: The third dimension: the } \\
\text { predictable opportunities and threats. }\end{array}$ & 3.8115 & .53527 & .02546 & \multirow[t]{2}{*}{$-58.966-$} & \multirow[t]{2}{*}{.000} & \multirow[t]{2}{*}{.763} & \multirow[t]{2}{*}{.000} \\
\hline & $\begin{array}{l}\text { a2: Employees' knowledge and } \\
\text { efficiency }\end{array}$ & 4.7828 & .41280 & .01964 & & & & \\
\hline \multirow[t]{2}{*}{ Pair 7} & $\begin{array}{l}\text { TotalA: The first dimension: the } \\
\text { benefits. }\end{array}$ & 4.8747 & .27866 & .01325 & \multirow[t]{2}{*}{$-5.049-$} & \multirow[t]{2}{*}{.000} & \multirow[t]{2}{*}{.869} & \multirow[t]{2}{*}{.000} \\
\hline & $\begin{array}{l}\text { a5: Safety and infections prevention } \\
\text { such. }\end{array}$ & $\begin{array}{r}4.90 \\
95\end{array}$ & $\begin{array}{r}.2872 \\
2\end{array}$ & $\begin{array}{r}.0136 \\
6\end{array}$ & & & & \\
\hline \multirow[t]{2}{*}{ Pair 8} & $\begin{array}{l}\text { TotalB: The second dimension: } \\
\text { reality (Strengths and Weaknesses) }\end{array}$ & 3.5730 & .52342 & .02490 & \multirow[t]{2}{*}{$\begin{array}{l}-63.950- \\
-1\end{array}$} & \multirow[t]{2}{*}{.000} & \multirow[t]{2}{*}{.543} & \multirow[t]{2}{*}{.000} \\
\hline & a5: Safety and infections prevention. & 4.9095 & .28722 & .01366 & & & & \\
\hline \multirow[t]{2}{*}{ Pair 9} & $\begin{array}{l}\text { TotalC: The third dimension: the } \\
\text { predictable opportunities and threats. }\end{array}$ & 3.8115 & .53527 & .02546 & \multirow[t]{2}{*}{$-52.825-$} & \multirow[t]{2}{*}{.000} & \multirow[t]{2}{*}{.579} & \multirow[t]{2}{*}{.000} \\
\hline & a5: Safety and infections prevention. & 4.9095 & .28722 & .01366 & & & & \\
\hline \multirow[t]{2}{*}{ Pair 10} & $\begin{array}{l}\text { TotalA: The first dimension: the } \\
\text { benefits. }\end{array}$ & 4.8747 & .27866 & .01325 & \multirow[t]{2}{*}{$-7.648-$} & \multirow[t]{2}{*}{.000} & \multirow[t]{2}{*}{.720} & \multirow[t]{2}{*}{.000} \\
\hline & a10: CCM. & 4.9457 & .22686 & .01079 & & & & \\
\hline \multirow[t]{2}{*}{ Pair 11} & $\begin{array}{l}\text { TotalB: The second dimension: } \\
\text { reality (Strengths and Weaknesses) }\end{array}$ & 3.5730 & .52342 & .02490 & \multirow[t]{2}{*}{$-60.600-$} & \multirow[t]{2}{*}{.000} & \multirow[t]{2}{*}{.415} & \multirow[t]{2}{*}{.000} \\
\hline & a10: CCM. & 4.9457 & .22686 & .01079 & & & & \\
\hline \multirow[t]{2}{*}{ Pair 12} & $\begin{array}{l}\text { TotalC: The third dimension: the } \\
\text { predictable opportunities and threats. }\end{array}$ & 3.8115 & .53527 & .02546 & \multirow[t]{2}{*}{$-49.950-$} & \multirow[t]{2}{*}{.000} & \multirow[t]{2}{*}{.453} & \multirow[t]{2}{*}{.000} \\
\hline & a10: CCM. & 4.9457 & .22686 & .01079 & & & & \\
\hline
\end{tabular}

Regarding Employees opinion concerning, the effect of the main variables of the study (Employees' knowledge and efficiency; safety and infections prevention; CCM; and service automation and robotic) on Guest' satisfaction.

The first hypotheses were tested using NPar Tests "Kruskal-Wallis Test". Test Statistics $^{\mathbf{a}, \mathbf{b}}$ (a. Kruskal Wallis Test for Employees' knowledge and efficiency; safety and infections prevention ; CCM; and service automation and robotic) and b. Grouping Variable: Guest' Satisfaction. Results shows that there is a statically differences in accordance Guest' Satisfaction on Employees opinion regarding the role of service automation and robotic in the Egyptian hotels, with (Chi-Square) values ranging from (31.273) to (214.347); Asymp. Sig. (.000) this indicate there is statistically significant relations. Results indicate that the role of (Employees' knowledge and efficiency; safety and infections prevention; CCM; and service automation and robotic) in the Egyptian hotels have a statically differences in accordance Guest' Satisfaction. This agreed with H1.

On other word: service automation and robotic have an impact on the Guest' Satisfaction the results show that the first dimension: the benefits positively influence the Guest' Satisfaction with (Chi-Square) value (67.179), Asymp. Sig. (0.000), the second dimension: reality (Strengths and Weaknesses) positively influences the Guest' Satisfaction with (Chi-Square) value (31.273), Asymp. Sig. (0.000); the third dimension: the predictable opportunities and threats positively influence the Guest' Satisfaction with (Chi-Square) value (31.565), Asymp, Sig. (0.000). These indicate there are statistically significant relations. These results agreed with H1A: Applying the SART in the Egyptian hotels positively influences the Guest' Satisfaction. As shown in table (8). 


\section{Table 8}

The effect of the main variables of the study on Guest' satisfaction NPar Tests

\begin{tabular}{|c|c|c|c|c|c|}
\hline \multicolumn{4}{|c|}{ Ranks } & \multicolumn{2}{|c|}{$\begin{array}{c}\text { Test } \\
\text { Statistics }^{\mathrm{a}, \mathrm{b}}\end{array}$} \\
\hline & $\begin{array}{l}\text { a1: Guest' } \\
\text { Satisfaction. }\end{array}$ & $\mathrm{N}$ & $\begin{array}{l}\text { Mean } \\
\text { Rank }\end{array}$ & $\begin{array}{c}\text { Chi- } \\
\text { Square }\end{array}$ & $\begin{array}{l}\text { Asymp. } \\
\text { Sig. }\end{array}$ \\
\hline \multirow{2}{*}{$\begin{array}{l}\text { a2: Employees' knowledge and } \\
\text { efficiency }\end{array}$} & Agree & 12 & 48.50 & \multirow{2}{*}{44.356} & \multirow{2}{*}{.000} \\
\hline & Strongly agree & 430 & 226.33 & & \\
\hline \multirow{2}{*}{$\begin{array}{l}\text { a5: Safety and infections } \\
\text { prevention. }\end{array}$} & Agree & 12 & 20.50 & \multirow{2}{*}{123.685} & \multirow{2}{*}{.000} \\
\hline & Strongly agree & 430 & 227.11 & & \\
\hline \multirow[t]{2}{*}{ a10: CCM. } & Agree & 12 & 12.50 & \multirow{2}{*}{214.347} & \multirow{2}{*}{.000} \\
\hline & Strongly agree & 430 & 227.33 & & \\
\hline \multirow{2}{*}{$\begin{array}{l}\text { TotalA: The first dimension: the } \\
\text { benefits. }\end{array}$} & Agree & 12 & 6.50 & \multirow{2}{*}{67.179} & \multirow{2}{*}{.000} \\
\hline & Strongly agree & 430 & 227.50 & & \\
\hline \multirow{2}{*}{$\begin{array}{l}\text { TotalB: The second dimension: } \\
\text { reality (Strengths and Weaknesses) }\end{array}$} & Agree & 12 & 18.50 & \multirow{2}{*}{31.273} & \multirow{2}{*}{.000} \\
\hline & Strongly agree & 430 & 227.17 & & \\
\hline \multirow{2}{*}{$\begin{array}{l}\text { TotalC: The third dimension: the } \\
\text { predictable opportunities and } \\
\text { threats. }\end{array}$} & Agree & 12 & 18.50 & \multirow{2}{*}{31.565} & \multirow[b]{2}{*}{.000} \\
\hline & Strongly agree & 430 & 227.17 & & \\
\hline
\end{tabular}

a. Kruskal Wallis Test

b. Grouping Variable: a1 : Guest' Satisfaction

To demonstrate the effect of different degrees of statistical significance between the mean of the different variables that effect the role of SART as a Tool Support CCM and Increase Guest' Satisfaction in the Egyptian hotels in accordance to the different employees' positions, analysis of variance - ANOVA was used.

A one-way ANOVA method was used to study a role of SART from the different employees' positions; they are three dimensions: The first dimension: the benefits; the second dimension: reality "Strengths and Weaknesses"; and The third dimension: the predictable opportunities and threats. As well as, evaluate the impact of the employees' positions on the main study variables (Guest' Satisfaction, Employees' knowledge and efficiency, Safety and infections prevention.

The study evaluates the employees' vision regarding the impact of employees' positions on evaluating the main study variables (SART, Guest' Satisfaction, Employees' knowledge and efficiency, Safety and infections prevention, CCM). As a comparison of both the scale and application possibility of the employees' positions point of views and the extent of application of SART.

On the other hand, compared to evaluating the employees' vision regarding the impact of SART as a Tool Support CCM and Increase Guest' Satisfaction. Therefore, the important result means that (The extent of Guest' Satisfaction the value for F was " 31.545 " and evaluating the employees' vision regarding the CCM. the value for F was " 84.121 ", with Sig "0.000". These indicate there are statistically significant relations, as shown in table (9). 


\section{Table 9}

One-way analysis of variance - ANOVA to compare the impact of the respondents' opinions regarding SART in accordance to the positions

\begin{tabular}{|c|c|c|c|c|c|c|}
\hline \multicolumn{7}{|c|}{ ANOVA } \\
\hline & & $\begin{array}{l}\text { Sum of } \\
\text { Squares }\end{array}$ & $\mathrm{df}$ & $\begin{array}{l}\text { Mean } \\
\text { Squar } \\
\text { e }\end{array}$ & $\mathrm{F}$ & Sig. \\
\hline \multirow{3}{*}{ a1: Guest' Satisfaction. } & Between Groups & 2.074 & 3 & .691 & 31.545 & .000 \\
\hline & Within Groups & 9.600 & 438 & .022 & & \\
\hline & Total & 11.674 & 441 & & & \\
\hline \multirow{3}{*}{$\begin{array}{l}\text { a2: Employees' } \\
\text { knowledge and efficiency }\end{array}$} & Between Groups & 45.177 & 3 & $\begin{array}{c}15.05 \\
9\end{array}$ & 220.067 & .000 \\
\hline & Within Groups & 29.972 & 438 & .068 & & \\
\hline & Total & 75.149 & 441 & & & \\
\hline \multirow{3}{*}{$\begin{array}{l}\text { a5: Safety and infections } \\
\text { prevention such. }\end{array}$} & Between Groups & 23.047 & 3 & 7.682 & 252.362 & .000 \\
\hline & Within Groups & 13.333 & 438 & .030 & & \\
\hline & Total & 36.380 & 441 & & & \\
\hline \multirow{3}{*}{ a10: CCM. } & Between Groups & 8.297 & 3 & 2.766 & 84.121 & .000 \\
\hline & Within Groups & 14.400 & 438 & .033 & & \\
\hline & Total & 22.697 & 441 & & & \\
\hline \multirow{3}{*}{$\begin{array}{l}\text { TotalA: The first } \\
\text { dimension: the benefits. }\end{array}$} & Between Groups & 29.408 & 3 & 9.803 & 887.992 & .000 \\
\hline & Within Groups & 4.835 & 438 & .011 & & \\
\hline & Total & 34.243 & 441 & & & \\
\hline \multirow{3}{*}{$\begin{array}{l}\text { TotalB: The second } \\
\text { dimension: reality } \\
\text { (Strengths and } \\
\text { Weaknesses) }\end{array}$} & Between Groups & 99.364 & 3 & $\begin{array}{c}33.12 \\
1 \\
\end{array}$ & 676.163 & .000 \\
\hline & Within Groups & 21.455 & 438 & .049 & & \\
\hline & Total & 120.819 & 441 & & & \\
\hline \multirow{3}{*}{$\begin{array}{l}\text { TotalC: The third } \\
\text { dimension: the predictable } \\
\text { opportunities and threats. }\end{array}$} & Between Groups & 105.78 & 3 & 35.26 & 750.755 & .000 \\
\hline & Within Groups & 20.571 & 438 & .047 & & \\
\hline & Total & 126.351 & 441 & & & \\
\hline
\end{tabular}

The first hypotheses were tested using NPar Tests "Kruskal-Wallis Test". Test Statistics $^{\mathbf{a}, \mathbf{b}}$ (a. Kruskal Wallis Test for the impact of applying SART in the development on the main variables of the study ( Guest' Satisfaction ; Employees' knowledge and efficiency; safety and infections prevention; CCM) ; and b. Grouping Variable: position). Results shows that there is strong impact of the applying SART on Guest' Satisfaction, CCM and the other variables, with (Chi-Square) values ranging from (78.354) to (372.420); Asymp. Sig. (.000) this indicate there is statistically significant relations. As shown in table (10).

On other words: The effect of the respondents' opinions regarding SART in accordance to the resonant' positions NPar Tests were as following :Results shows that there is strong impact of the applying SART on Safety and infections prevention, with (Chi-Square) values ranging (279.373); there is strong impact of the applying SART on a2: Employees' knowledge and efficiency, with (Chi-Square) values 
ranging (265.114); there is strong impact of the applying SART on a10: CCM, with (Chi-Square) values ranging (161.208); there is strong impact of the applying SART on a1: Guest' Satisfaction, with (Chi-Square) values ranging (78.354); all Asymp. Sig. were (.000) these indicate there is statistically significant relations. These results agreed with H1: There is a significant impact of applying SART in the development on the variables.

\section{Table 10}

The effect of the respondents' opinions regarding SART in accordance to the resonant' positions NPar Tests.

\begin{tabular}{|c|c|c|c|c|c|}
\hline \multicolumn{4}{|c|}{ Ranks } & \multicolumn{2}{|c|}{ Test Statisticsa,b } \\
\hline & Resonant' positions & $\mathrm{N}$ & $\begin{array}{l}\text { Mean } \\
\text { Rank }\end{array}$ & $\begin{array}{c}\text { Chi- } \\
\text { Square }\end{array}$ & $\begin{array}{c}\text { Asymp } \\
\text { Sig. }\end{array}$ \\
\hline \multirow{4}{*}{ a1: Guest' Satisfaction. } & Employee "team member" & 60 & 183.30 & \multirow{4}{*}{78.354} & \multirow{4}{*}{.000} \\
\hline & Supervisor Operational & 215 & 227.50 & & \\
\hline & Departmental head & 139 & 227.50 & & \\
\hline & Manager & 28 & 227.50 & & \\
\hline \multirow{4}{*}{$\begin{array}{l}\text { a2: Employees' } \\
\text { knowledge and } \\
\text { efficiency }\end{array}$} & Employee "team member" & 60 & 48.50 & \multirow{4}{*}{265.114} & \multirow{4}{*}{.000} \\
\hline & Supervisor Operational & 215 & 232.50 & & \\
\hline & Departmental head & 139 & 269.50 & & \\
\hline & Manager & 28 & 269.50 & & \\
\hline \multirow{4}{*}{$\begin{array}{l}\text { a5: Safety and infections } \\
\text { prevention such. }\end{array}$} & Employee "team member" & 60 & 94.17 & \multirow{4}{*}{279.373} & \multirow{4}{*}{.000} \\
\hline & Supervisor Operational & 215 & 241.50 & & \\
\hline & Departmental head & 139 & 241.50 & & \\
\hline & Manager & 28 & 241.50 & & \\
\hline \multirow{4}{*}{ a10: CCM. } & Employee "team member" & 60 & 145.10 & \multirow{4}{*}{161.208} & \multirow{4}{*}{.000} \\
\hline & Supervisor Operational & 215 & 233.50 & & \\
\hline & Departmental head & 139 & 233.50 & & \\
\hline & Manager & 28 & 233.50 & & \\
\hline \multirow{4}{*}{$\begin{array}{l}\text { TotalA: The first } \\
\text { dimension: the benefits. }\end{array}$} & Employee "team member" & 60 & 30.77 & \multirow{4}{*}{308.947} & \multirow{4}{*}{.000} \\
\hline & Supervisor Operational & 215 & 237.44 & & \\
\hline & Departmental head & 139 & 269.50 & & \\
\hline & Manager & 28 & 269.50 & & \\
\hline \multirow{4}{*}{$\begin{array}{l}\text { TotalB: The second } \\
\text { dimension: reality } \\
\text { (Strengths and } \\
\text { Weaknesses) }\end{array}$} & Employee "team member" & 60 & 32.10 & \multirow{4}{*}{372.420} & \multirow{4}{*}{.000} \\
\hline & Supervisor Operational & 215 & 168.02 & & \\
\hline & Departmental head & 139 & 344.68 & & \\
\hline & Manager & 28 & 426.50 & & \\
\hline \multirow{4}{*}{$\begin{array}{l}\text { TotalC: The third } \\
\text { dimension: the } \\
\text { predictable opportunities } \\
\text { and threats. }\end{array}$} & Employee "team member" & 60 & 34.50 & \multirow{4}{*}{368.030} & \multirow{4}{*}{.000} \\
\hline & Supervisor Operational & 215 & 168.51 & & \\
\hline & Departmental head & 139 & 342.88 & & \\
\hline & Manager & 28 & 426.50 & & \\
\hline
\end{tabular}

a. Kruskal Wallis Test

b. Grouping Variable: position

Moreover; there is a role of SART on support CCM and increase Guest'

Satisfaction. a. Friedman Test shows that evaluating the employees' vision regarding 
the impact of the SART support CCM and increase Guest' Satisfaction were the 'higher main rank and agree with Mean Rank (5.24) followed by the impact of the SART support CCM with Mean Rank (5.15) . Regarding, evaluating the employees' vision regarding the impact of SART on support CCM and increase Guest' Satisfaction.

The results also showed that Chi-Square 2468.463 and the parameter ratio Sig. (0.000). This means that there is an effect of different degrees of statistical significance between the average of the different variables that measure the role of SART in the main variables of the study (Guest' Satisfaction ; Employees' knowledge and efficiency; safety and infections prevention; CCM). These confirm the H1: There is a significant impact of applying SART in the development on the main variables of the study (Guest' Satisfaction ; Employees' knowledge and efficiency; safety and infections prevention; CCM). As shown in table (11).

\section{Table 11}

a Friedman Test among the various variables that influence the role of service automation and robotic in CCM and Guest' Satisfaction (N. 442).

\begin{tabular}{|c|c|c|c|c|c|}
\hline \multirow[b]{2}{*}{$\frac{8}{8}$} & \multicolumn{2}{|l|}{ Ranks } & \multicolumn{3}{|c|}{ a. Friedman Test (N. 442). } \\
\hline & & $\begin{array}{l}\text { Mean } \\
\text { Rank }\end{array}$ & Chi-Square & df & $\begin{array}{l}\text { Asymp. } \\
\text { Sig. }\end{array}$ \\
\hline a1 & Guest' Satisfaction. & 5.24 & \multirow{7}{*}{2468.463} & \multirow{7}{*}{6} & \multirow{7}{*}{.000} \\
\hline $\mathbf{a} 2$ & $\begin{array}{l}\text { Employees' knowledge and } \\
\text { efficiency }\end{array}$ & 4.67 & & & \\
\hline a5 & Safety and infections prevention. & 5.05 & & & \\
\hline a10 & CCM. & 5.15 & & & \\
\hline TotalA & The first dimension: the benefits. & 4.90 & & & \\
\hline TotalB & $\begin{array}{l}\text { The second dimension: reality } \\
\text { (Strengths and Weaknesses) }\end{array}$ & 1.00 & & & \\
\hline TotalC & $\begin{array}{l}\text { The third dimension: the predictable } \\
\text { opportunities and threats. }\end{array}$ & 2.00 & & & \\
\hline
\end{tabular}

H2: There are significant relationships between the main variables of the study (Service automation and robotic; Guest' Satisfaction; Employees' knowledge and efficiency; safety and infections prevention; CCM). As shown in table (11) and figure (2).

Regarding the research hypothesis test H2: There are significant relationships between the main variables of the study (Service automation and robotic; Guest' Satisfaction; Employees' knowledge and efficiency; safety and infections prevention; CCM). Research hypotheses were tested using Pearson correlation coefficient. Analyses were done to ensure that no violation of assumptions of normality and linearity.

Results showed that there is a significant correlation between the benefits; strangeness and weakness points "reality"; and the predictable opportunities and threats of SART. With $(\mathrm{r})$ values ranging from $(0.290)$ to $(0.982)(\mathrm{p}<.01) * *$. The correlation was significant at the 0.01 level (2-tailed). Based on the results of Pearson correlation 
analysis which represent proposed linear relationship, all the research hypotheses were positive and supported.

On other words, Results showed that there is a significant correlation between: (1) Applying the SART vs the Guest' Satisfaction, with (r) values (0 .525**), and p (.000). (2) Adapting appropriate system of SART vs Employees' knowledge and efficiency, with $(\mathrm{r})$ values $\left(0.855^{* *}\right)$, and $\mathrm{p}(.000)$. (3) Using SART vs safety and infections prevention, with ( $\mathrm{r}$ ) values $(0.869 * *)$, and $\mathrm{p}(.000)$. (4) Using SART vs CCM, with (r) values $\left(0.720^{* *}\right)$, and $\mathrm{p}(.000)$. The following tables (12-13) illustrate that:

\section{Table 12}

The relationships between the main variables of the study.

\begin{tabular}{|c|c|c|c|c|c|c|c|c|}
\hline \multicolumn{9}{|c|}{ Correlations } \\
\hline & & a1 & $\mathrm{a} 2$ & a5 & a10 & $\begin{array}{c}\text { Total } \\
\text { A }\end{array}$ & $\begin{array}{c}\text { Total } \\
\text { B }\end{array}$ & $\begin{array}{l}\text { Tot } \\
\text { alC }\end{array}$ \\
\hline \multirow{2}{*}{ a1: Guest' Satisfaction. } & Pearson Correlation & 1 & & & & & & \\
\hline & Sig. (2-tailed) & & & & & & & \\
\hline \multirow{2}{*}{$\begin{array}{l}\text { a2: Employees' knowledge } \\
\text { and efficiency }\end{array}$} & Pearson Correlation & $.317 * *$ & 1 & & & & & \\
\hline & Sig. (2-tailed) & .000 & & & & & & \\
\hline \multirow{2}{*}{$\begin{array}{l}\text { a5: Safety and infections } \\
\text { prevention. }\end{array}$} & Pearson Correlation & $.530 * *$ & $.599 * *$ & 1 & & & & \\
\hline & Sig. (2-tailed) & .000 & .000 & & & & & \\
\hline \multirow{2}{*}{ a10: CCM. } & Pearson Correlation & $.697 * *$ & $.455^{* *}$ & $.760 * *$ & 1 & & & \\
\hline & Sig. (2-tailed) & .000 & .000 & .000 & & & & \\
\hline \multirow{2}{*}{$\begin{array}{l}\text { TotalA: The first } \\
\text { dimension: the benefits. }\end{array}$} & Pearson Correlation & $.525 * *$ & $.855 * *$ & $.869 * *$ & $.720 * *$ & 1 & & \\
\hline & Sig. (2-tailed) & .000 & .000 & .000 & .000 & & & \\
\hline \multirow{2}{*}{$\begin{array}{l}\text { TotalB: The second } \\
\text { dimension: reality } \\
\text { (Strengths and Weaknesses) }\end{array}$} & Pearson Correlation & $.290 * *$ & $.734 * *$ & $.543 * *$ & $.415^{* *}$ & $.695 * *$ & 1 & \\
\hline & Sig. (2-tailed) & .000 & .000 & .000 & .000 & .000 & & \\
\hline \multirow{2}{*}{$\begin{array}{l}\text { TotalC: The third } \\
\text { dimension: the predictable } \\
\text { opportunities and threats. }\end{array}$} & Pearson Correlation & $.316^{* * *}$ & $.763 * *$ & $.579 * *$ & $.453 * *$ & $.742 * *$ & $.982 * *$ & 1 \\
\hline & Sig. (2-tailed) & .000 & .000 & .000 & .000 & .000 & .000 & \\
\hline
\end{tabular}

**. Correlation is significant at the 0.01 level (2-tailed). $(\mathrm{p}<.01)$. r: Pearson coefficient

\section{Table 13}

Hypothesis test summary.

\begin{tabular}{|l|c|c|c|}
\hline \multicolumn{1}{|c|}{ Null Hypothesis } & Test & Sig. & Decision \\
\hline $\begin{array}{l}\text { The distribution of a1, a2, } \\
\text { a5, a10, totalA, totalB, and } \\
\text { totalC are the same. }\end{array}$ & $\begin{array}{c}\text { Related Samples Friedman's } \\
\text { Two way analysis of variance } \\
\text { by ranks }\end{array}$ & 0.000 & $\begin{array}{c}\text { reject the null } \\
\text { hypothesis }\end{array}$ \\
\hline
\end{tabular}

Asymptotic significances are displayed. The significance level is 0.05 . 
Hypothesis Test Summary

\begin{tabular}{|c|c|c|c|c|}
\hline & Null Hypothesis & Test & Sig. & Decision \\
\hline 1 & $\begin{array}{l}\text { The distributions of a1, } a 2 \text {, a5, a10 } \\
\text { totalA, totalB and totaic are the } \\
\text { same. }\end{array}$ & $\begin{array}{l}\text { Related- } \\
\text { Samples } \\
\text { Friedman's } \\
\text { Tuno-viay } \\
\text { Analysis of } \\
\text { Wariance by } \\
\text { Ranks }\end{array}$ & م000. & $\begin{array}{l}\text { Reject the } \\
\text { null } \\
\text { hypothesis. }\end{array}$ \\
\hline
\end{tabular}

Asymptotic significances are displayed. The significance level is .05.

\section{Conclusions}

Fig.3. Hypothesis test summary

Concerning the employees' opinion towards the first dimension: the benefits the results showed that it's importance to apply the SART to: increase Guest' Satisfaction, support CCM to enhance guests' satisfaction. Have a role in increase the level of services process to enhance guests' satisfaction. Have effective role in safety and infections prevention as well as read guests' expectations and needs. Increase customer' orientation to enhance guests' satisfaction. Increase employees' satisfaction. Support the business revenue and profit increases. Increase Internet based communication tools to enhance guests' satisfaction. Play a major role in influencing guest choice for the hotel; provide increased guest 'retention; positively influences Loyalty programs. Positively influences Employees' knowledge and efficiency. increase positively Employees' knowledge and efficiency These results agreed with (Lorde et al., 2011; Gökalp and Eren, 2013; Trejos, 2015; Gladstone, 2016; Kelly et al., 2017; Smirnova et al., 2017; Kim and Kim, 2018; Tussyadiah and Park, 2018; Ivanov, 2019; Murphy et al., 2019) .

According to the second dimension: the strangeness and weakness points "reality" results showed the strong points were: SART are newly emerging technologies in hospitality services. There is a relationship between SART and Guest' Satisfaction. The Smart mini-bars provide fast service and automatic billing. The hotels care about fast and automatic service and billing. The hotels exploit their services using different Service Automation Technologies and CCM apps and practices. Hotels are using different Service Automation Technologies and CCM apps and practices. Hotel ensures that SART improve service performance and increase the guest satisfaction, the Hotel ensures that SART improve service performance and increase Guest' Satisfaction. These results agreed with (Law et al., 2014; Tong, 2015; Tung and Au, 2018; Ivanov, 2019; Webster and Ivanov, 2020).

On the other side regarding the weaknesses were: Egyptian hotels need more care about in-room resource access is the system that intelligently adjusts comfortable temperature and the air conditioner off when no one is in the room. Egyptian hotels need more care regarding applied SART. Egyptian hotels need more care regarding applied SART. The hotels need more care regarding in-room ambience. Hotels need more care regarding identity recognition system which identifies the guests and their 
access. These results agreed with (Kelly et al., 2017; Kim and Kim, 2018; Tussyadiah and Park, 2018).

According to the third dimension: the predictable opportunities the results showed that: the SART are fast changing; this indicated that SART need continues awareness and developments. SART need training; training needs to be continuously. The SART is still expensive, SART need high investment. SART need continuous improvement in Egypt, These results agreed with (Tussyadiah and Park, 2018; Tung and Au, 2018; Youssef et al., 2018).

On the other side, According to the third dimension: the threats the results showed that: Egyptian hotels systems are not adequately preparing us for SART, this indicates that the hotels need more care regarding the adequate systems preparing. Egyptian hotels are not well aware of the effect of SART. And the activities SART are consistent with Egyptian hotels. Hotels need to consistent with and improve the awareness about the effect of SART. Egyptian hotels are not effectively implement adequate SART, this indicates that Egyptian hotels need more care regarding the effectively implement of adequate SART. Employees show that they have not good awareness level regarding SART; this indicates that hotels need more care regarding improving employees' awareness regarding SART. These results agreed with (Kuo and Boger, 2016; Murphy, 2017 ${ }^{\mathrm{A} ;}$ Qiu et al., 2019).

Research hypotheses were H1: There is a significant impact difference of applying SART in the development on the main variables of the study. H2: There are significant relationships between the main variables of the study. Research hypotheses were tested and statically analyzed.

The hotel employees' Preferences Regarding the effect of using service automation and robotic technologies (SART) in Egyptian hotels model

The process of developing was a ranking model regarding the managers' evaluation regarding the effect of using service automation and robotic technologies (SART) in Egyptian hotels which aim to shed light on the most recurrent importance and situation as well as SWOT analysis of using (SART) in Egyptian hotels from the perspectives of the hotel employees so as to improve the guests' satisfaction. The aim of this model was to shed the light on the most important attributes of Facilities SART from the perspectives of employees and managers in order to better meet the guest satisfaction (see table 14). 


\section{Table 14}

Evaluating the employees' vision regarding the SART in the Egyptian hotels Model

\begin{tabular}{|c|c|c|c|c|}
\hline$\dot{0}$ & $\frac{\pi}{0}$ & Factor & 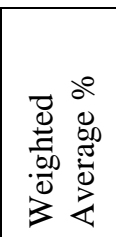 & 宸 \\
\hline & & The first dimension: the benefits & & \\
\hline 1. & a1 & $\begin{array}{l}\text { Applying the SART in the Egyptian hotels positively influences } \\
\text { the guest' satisfaction. }\end{array}$ & 99.46 & 1 \\
\hline 2. & a10 & $\begin{array}{l}\text { Adapting appropriate system of SART efficiency positively } \\
\text { influences CCM. }\end{array}$ & 98.91 & 2 \\
\hline 3. & a9 & SART positively increase the level of services process. & 98.73 & 3 \\
\hline 4. & a5 & $\begin{array}{l}\text { Adapting appropriate system of SART efficiency positively } \\
\text { influences assuring safety and infections prevention. }\end{array}$ & 98.19 & $4^{*}$ \\
\hline 5. & a12 & $\begin{array}{l}\text { SART helps the hotel to determine guests' expectations and } \\
\text { needs. }\end{array}$ & 98.19 & $4 *$ \\
\hline 6. & a11 & SART positively increase customer' orientation. & 97.83 & 5 \\
\hline 7. & a13 & SART affect employees' satisfaction. & 97.65 & 6 \\
\hline 8. & a6 & SART support the business revenue and profit increases. & 97.10 & 7 \\
\hline 9. & a7 & $\begin{array}{l}\text { SART to increase Internet based communication tools to enhance } \\
\text { guests' satisfaction. }\end{array}$ & 96.56 & 8 \\
\hline 10. & a3 & $\begin{array}{l}\text { Using SART play a major role in influencing guest choice for the } \\
\text { hotel. }\end{array}$ & 96.38 & $9 *$ \\
\hline 11. & a4 & SART systems provide increased guest' retention. & 96.38 & $9 *$ \\
\hline 12. & a8 & $\begin{array}{l}\text { Adapting appropriate system of SART positively influences } \\
\text { loyalty programs. }\end{array}$ & 96.38 & $9 *$ \\
\hline 13. & a2 & $\begin{array}{l}\text { Adapting appropriate system of SART positively influences } \\
\text { Employees' knowledge and efficiency. }\end{array}$ & 95.66 & 10 \\
\hline & & The second dimension: reality (Strengths and Weaknesses) & & \\
\hline 1. & b18 & SART newly emerging technologies in hospitality services & 98.37 & 1 \\
\hline 2. & b17 & $\begin{array}{l}\text { There is a relationship between your expectations, satisfaction and } \\
\text { SART. }\end{array}$ & 98.01 & 2 \\
\hline 3. & b14 & Smart mini-bars provide service and automatic billing. & 87.78 & 3 \\
\hline 4. & b15 & $\begin{array}{l}\text { Hotel ensures that SART improve service performance and } \\
\text { increase your satisfaction. }\end{array}$ & 76.47 & 4 \\
\hline 5. & b16 & The hotel exploits their services using different SART. & 74.48 & 5 \\
\hline 6. & b5 & $\begin{array}{l}\text { Self-Check-in process where a guest selects the room on his own } \\
\text { through his own mobile device or the hotel kiosk. }\end{array}$ & 75.29 & 6 \\
\hline 7. & b1 & SART applications applied in Egypt & 74.30 & $7 *$ \\
\hline 8. & b12 & Contactless automation payment system. & 74.30 & 7* \\
\hline 9. & b13 & Tracking children by using RFID. & 69.37 & 8 \\
\hline 10. & b10 & $\begin{array}{l}\text { Personalization based on the profile database record the past } \\
\text { history of the guests regarding climate, mini-bar usage, and TV. }\end{array}$ & 66.02 & 9 \\
\hline 11. & $\mathrm{~b} 4$ & $\begin{array}{l}\text { Management is very sensitive to the service automation } \\
\text { technologies that were already going on within the company and } \\
\text { seek mean to support them. }\end{array}$ & 65.75 & $10^{*}$ \\
\hline 12. & b11 & $\begin{array}{l}\text { For the smart employees such as waitress service by using hand- } \\
\text { held device for recommending menu items to the guests. }\end{array}$ & 65.79 & $10^{*}$ \\
\hline 13. & b3 & Hotels management in Egypt directs good budgets to SART. & 63.21 & 11 \\
\hline & & & \multicolumn{2}{|c|}{ continued } \\
\hline
\end{tabular}




\begin{tabular}{|l|r|l|r|r|}
\hline 14. & b9 & Automatic voice recognition for service access. & 61.99 & 12 \\
\hline 15. & $\mathrm{~b} 6$ & $\begin{array}{l}\text { Identity recognition system which identifies the guests and access } \\
\text { permissions. }\end{array}$ & 60.77 & 13 \\
\hline 16. & $\mathrm{~b} 8$ & $\begin{array}{l}\text { In-room ambience adjustment is provided by smart walls which are } \\
\text { inherently large displays. }\end{array}$ & 59.82 & 14 \\
\hline 17. & $\mathrm{~b} 2$ & SART are well applied in Egyptian hotels. & 58.37 & 15 \\
\hline 18. & $\mathrm{~b} 7$ & $\begin{array}{l}\text { In-room resource access system that adjusts comfortable } \\
\text { temperature. }\end{array}$ & 56.20 & 16 \\
\hline & & $\begin{array}{l}\text { The third dimension: the predictable opportunities and } \\
\text { threats }\end{array}$ & & \\
\hline 1. & $\mathrm{c5}$ & SART are fast changing. & 96.38 & 1 \\
\hline 2. & $\mathrm{c} 2$ & SART need training. & 94.57 & 2 \\
\hline 3. & $\mathrm{c} 1$ & Applying SART still expensive. & 90.68 & 3 \\
\hline 4. & $\mathrm{c} 3$ & SART need high investment. & 77.47 & 4 \\
\hline 5. & $\mathrm{c} 4$ & SART need continuous improvement in Egypt. & 70.14 & 6 \\
\hline 6. & $\mathrm{c} 9$ & $\begin{array}{l}\text { Employees show that they have good awareness level regarding } \\
\text { SART. }\end{array}$ & 66.83 & 7 \\
\hline 7. & $\mathrm{c} 8$ & Egyptian hotels are effectively implementing adequate SART. \\
\hline 8. & $\mathrm{c} 7$ & Egyptian hotels are well aware of the effect of SART. & 62.35 & $8^{*}$ \\
\hline 9. & $\mathrm{c} 10$ & The activities SART are consistent with Egyptian hotels. & 62.35 & $8^{*}$ \\
\hline 10. & $\mathrm{c} 6$ & Egyptian hotels systems are adequately preparing us for SART. & 57.42 & 9 \\
\hline
\end{tabular}

The importance of this ranking model was to provide the perspectives regarding the most important guests' requirements and priorities for Facilities Technological Amenities, in order to better understand the guests' requirements for the role of applying technology at the guest room on the guest's choice of the hotel and trying to meet these requirements, which will lead to guest satisfaction and retention.

\section{Recommendations}

Referring to the previous conclusion the study recommends the following to improve the effect of using service automation and robotic technologies (SART) in Egyptian hotels:

\section{Recommendation}

1.Hotels managers should be fully aware of the guests' priorities regarding SART.

2.Hotels managers should be fully aware of guest' priorities regarding the role of applying SART at the guest services on the guest's choice of the hotel.

3.Hygiene and safety should be the first priorities of applying SART.

\section{Responsible for Implementation}

Hotels managers

Hotels managers

All employees , managers; and

Ministry of health
Mechanisms of Implementation

Research studies

Research studies

Apply the food safety system 
4.Guest' Satisfaction should be the core priorities of the SART.

5.Identify the factors and elements that would increase guest satisfaction through CCM programs.

6.Egyptian hotels should pay attention to evaluate and improve the SART continually.

7.Egyptian hotels should increase SART programs and introduce new practices frequency.

8.Hotels must develop a plan for The management SART to increase CCM.

9.Egyptian hotels should increase SART programs and introduce new practices frequency.

10. More attention should be paid to the aspect of SART inside hotels, through colleges and institutes of hotels, and a proposal to include the loyalty programs

11. Establishing and institutes to teach SART for hospitality industry are recommended.

12. Egyptian hotels should manage the weaknesses such as:

- Egyptian hotels need more care about in-room resource access system that adjusts temperature and the air conditioner off when no one is in the room.

- Egyptian hotels need more care regarding applied SART.

- The hotels need more care Engineering and regarding in-room ambience.
Engineering and maintenance \begin{tabular}{l|l} 
The hotel & Apply the SART and
\end{tabular}

management CCM practices

The hotel

management

Apply CCM practices

The hotel

management

Apply The quality assurance and developing systems

The hotel

Increase SART

programs and introduce new practices frequency.

Develop a strategic plans

The hotel

management

Increase SART programs and introduce new practices frequency

The hotel

management

Apply attractive loyalty programs

\begin{tabular}{c|l}
$\begin{array}{c}\text { Ministry of high } \\
\text { education }\end{array}$ & $\begin{array}{l}\text { Establishing and } \\
\text { institutes to teach SART } \\
\text { for hospitality }\end{array}$
\end{tabular}

Regular follow up and forecasting maintenance 


\begin{tabular}{l|l|l|} 
- Hotels need more care regarding & $\begin{array}{l}\text { Information } \\
\text { technologies } \\
\text { Identity recognition system which }\end{array}$ & $\begin{array}{l}\text { Identity recognition } \\
\text { system which identifies } \\
\text { identifies the guests and support } \\
\text { them access approvals. }\end{array}$
\end{tabular}

13. Egyptian hotels should care about the predictable threats such as:

- Egyptian hotels need more care regarding the adequate SART systems preparing.

- Hotels need to consistent with and improve the awareness about the effect of SART.

- Egyptian hotels need more care Quality assurance regarding the effectively implement of adequate SART.

- Egyptian hotels need more care regarding improving employees' skills regarding SART.

\begin{tabular}{c|l}
$\begin{array}{c}\text { Owners and } \\
\text { management }\end{array}$ & $\begin{array}{l}\text { adequate SART systems } \\
\text { preparing }\end{array}$
\end{tabular}

Training department Training and improve the awareness about the effect of SART

implement of adequate SART

Training
department
Training and improving employees' skills regarding SART.

\section{REFERENCES}

- Berezina, K. (2015). Mobility Convergence. Hotel Business Review. Retrieved on July 2020, from http://hotelexecutive.com/business_review/4178/mobilityconvergence

- Borràs, J., Moreno, A., \& Valls, A. (2014). Intelligent tourism recommender systems: A survey. Expert Systems with Applications, 41(16), 7370-7389.

- Chavez,R; Yu,W; Feng, M; and Wiengarten, F, (2016), The Effect of CustomerCentric Green Supply Chain Management on Operational Performance and Customer Satisfaction. Business Strategy and the Environment Bus. Strat. Env. 25, PP. 205-220.

- Curtis, S. (2016). Pizza Hut hires ROBOT waiters to take orders and process payments at its fast-food restaurants. Mirror. Retrieved July on 2020 from http://www.mirror.co.uk/tech/pizza-huthires- robot-waiters-8045172.

- Fridin, M., \& Belokopytov, M. (2014). Acceptance of socially assistive humanoid robot by preschool and elementary school teachers. Computers in Human Behavior, 33, 23-31.

- Fuchs, C , (2020) . Nationalism on the Internet: Critical Theory and Ideology in the Age of Social Media and Fake News. New York: Routledge

- Gihan, A \& Hany, K; (2015). Information Technology Impact on Hotel Business Sustainability", Bringing Practices to Improve the Hotel Performance", Journal of The Faculty of Tourism and Hotels Volume 12, Issue 1 PP. 71-90. 
- Gökalp, E and Eren, P.(2013). Impact of Pervasive Computing on Service Design in Hospitality, (O2013 Engineering and Technology Publishing, Journal of Advanced Management Science Vol. 1, No. 2, PP.241-245.

- Gladstone, N. (2016). Are robots the future of hotels? Retrieved on June1 2020 from: https://www.oyster.com/articles/53595arerobotsthefutureofhotels

- Hill, S. (2015). Restaurant table tablets: A gimmick, or actually helpful? The Christian Science Monitor. Retrieved on May 2020 From: http://www.csmonitor.com/Business/SavingMoney/2015/0514/Restaurant-tabletablets-Agimmick-or-actually-helpful

- Hill, N; Roche, G. and Allen, R. (2007). Customer Satisfaction: The Customer Experience through the Customer's Eyes. London: Cogent Publishing.

- Hilton. (2016). Hilton and IBM pilot "Connie," the world's first Watson-enabled hotel concierge. Retrieved on November 2020 from http://news.hiltonworldwide.com/index.cfm/news/hilton-and-ibm-pilot-conniethe-worlds-firstwatsonenabled-hotel-concierge

- Hilton Honors. (2017). Digital Check-in and Room Selection FAQ. Retrieved July 2020 from http://hiltonhonors3.hilton.com/en/mobile/digitalcheck- in-and-roomselection-faq.html.

- Ivanovic, S., Mikinac K., \&Perman. L. (2011). Customer Relation Management Development in Hospitality Companies for Increasing the Competitiveness in the Tourist Market. UTMS Journal of Economics 2 (1), p.p. 59-68.

- Ivanov, S. (2016) will robots substitute teachers? Paper presented at the 12th International Conference "Modern science, business and education", 27-29 June 2016, Varna University of Management, Bulgaria. Yearbook of Varna University of Management, Vol. 9, pp. 42-47.

- Ivanov, S. (2019). Ultimate transformation: How will automation technologies disrupt the travel, tourism and hospitality industries? Zeitschrift für Tourismuswissenschaft 11(1), 25-43.

- Ivanov, S; Webster, C and Berezina, K, (2018). Adoption of Robots and Service Automation by Tourism and Hospitality Companies. Revista Tur smo \& Desenvolvimento, No. 27/28, 2017 .PP. 1501 - 1517. E-ISSN 2182-1453. https://www.researchgate.net/publication/322635104_Adoption_of_robots_and_s ervice_automation_by_tourism_and_hospitality_companies [accessed Dec 08 2018].

- Kanda, T., \& Ishiguro, H. (2012). Human-Robot Interaction in Social Robotics. Boca Raton, FL: CRC Press.

- Kearns, J, (2010). Customer Retention Management in the Hospitality Industry: Profile of the Hotel Industry in Donegal. Master Research , Department Of Business School of Business Letterkenny Institute of Technology Word Count 12,155 .

- Kelly, P., Lawlor, J., \& Mulvey, M. (2017). Customer roles in self-service technology encounters in a tourism context. Journal of Travel \& Tourism Marketing, 34(2), 222-238. 
- Kim, H., \& Kim, B. G. (2018). A qualitative approach to automated motels: a rising issue in South Korea. International Journal of Contemporary Hospitality Management, 30(7), 2622-2636.

- Kim, M., \& Qu, H. (2014). Travelers' behavioral intention toward hotel selfservice kiosks usage. International Journal of Contemporary Hospitality Management, 26(2), 225-245.

- Kumar, D \& Kumar, P (2017). CRM: Impact on hotel industry. International Journal of Advanced Research and Development. ISSN: 2455-4030. Impact Factor: RJIF 5. 24. www.advancedjournal.com.

- Kumar, V., \& Reinartz, W. (2016 $\left.{ }^{\mathrm{A}}\right)$. Creating Enduring Customer Value. Journal of Marketing. doi:10.1509/JM.15.0414.In Press.

- Kumar, V., Dixit, A., Javalgi, R., \& Dass, M. (2016 $\left.{ }^{\mathrm{B}}\right)$. Research Framework, Strategies, and Applications of Intelligent Agent Technologies (Iats) in Marketing. Journal of the Academy of Marketing Science, 44(1), PP. 24-45.

- Kuo, M., Chen, C., \& Tseng, Y. (2017). Investigating an innovative service with hospitality robots. International Journal of Contemporary Hospitality Management, 29(5), 1305-1321.

- Kuo, M., Huang, S., Tseng, Y., \& Boger, P. (2016). SMART SWOT Strategic Planning Analysis: For Service Robot Utilization in the Hospitality Industry. Consortium Journal of Hospitality \& Tourism, 20(2), 60-72.

- Lanz, L; Ferrari, M; and Mody, M, (2020), Hospitality Communications in a Time of Coronavirus: Tips for Maintaining Trust and Engagement, Special Edition: COVID-19 Crisis. Boston University.

- Law, R., Buhalis, D., \& Cobanoglu, C. (2014). Progress on information and communication technologies in hospitality and tourism. International Journal of Contemporary Hospitality Management, 26(5), 727-750.

- López, J., Pérez, D., Zalama, E., \& Gómez-García-Bermejo, J. (2013). Bellbot-a hotel assistant system using mobile robots. International Journal of Advanced Robotic Systems, 10(1), 40.

- Lorde,T; Francis,B; and Drakes, R, (2011). "Tourism Services Exports and Economic Growth in Barbados," The International Trade Journal, vol. 25, no. 2, pp. 205-232.

- Maney, R., Flink, C \& Lietz, C. (2002), "White Paper On Consumer Centric Marketing: How Leading Consumer Packaged Goods Companies are Transforming the Way They Market", Available at: crm.ittoolbox.com/documents/document.asp?i = 2835 ", [Accessed on 06- 072019].

- Markoff, J. (2014). 'Beep,' says the bellhop. The New York Times. Retrieved on June 2020 from https:/www.nytimes.com/2014/08/12/technology/hotel-to-begintesting-botlr-a-robotic-bellhop.html?_r=0

- Marks, G. (2016, 19 December). A fully automated restaurant just opened in New York City (114 years after the last automated restaurant opened). Washington Post. Retrieved on August 2020 from https://www.washingtonpost.com/news/on- 
smallbusiness/wp/2016/12/19/a-fully-automated-restaurantjust-opened-in-newyork-city-114-years-after-the-lastautomated- restaurant-opened

- Marriott International, Inc. (2016). Mobile check-in. Retrieved on June 2020 from http://mobileapp.marriott.com/mobile-check-in/

- Mathies, C; Gudergan, S; \& Paul Z. Wang, P, (2014), The Effects of CustomerCentric Marketing and Revenue Management on Travelers' Choices, Journal of Travel Research 52(4), PP.479-493.

- Maurer, M., Gerdes, C., Lenz, B. \& Winner, H. (Eds.) (2016) Autonomous driving: technical, legal and social aspects. Berlin, Heidelberg: Springer Open.

- MGM Resorts International. (2017). Mobile check in. Retrieved on November 2020 from https://www.bellagio.com/en/hotel/checkin.html

- Min, H. (2010). Artificial intelligence in supply chain management: theory and applications. International Journal of Logistics Research and Applications, 13(1), 13-39.

- Minghetti, V, (2003). Building Customer Value in the Hospitality Industry: Towards the Definition of A Customer-Centric Information System. Information Technology \& Tourism, Vol. 6 pp. 141-152.

- Muriithi, C, (2015)."Effect of Consumer Centric Marketing on Performance of Hotels in Rwanda. Case Study of 2 and 3 Star Hotels and 4 and 5 Star Hotels Categories in Kigali", Research project report submitted to the Department of Business Administration in the School Business in partial fulfillment of the requirement for the award of the degree of Master in Business Administration (Marketing option). Jomo Kenyatta University of Agriculture and Technology.

- Murphy, J., Gretzel, U., \& Hofacker, C. (2017 $)$. Service Robots in Hospitality and Tourism: Investigating Anthropomorphism. Paper presented at the 15th APacCHRIE Conference, 31 May-2 June 2017, Bali, Indonesia. Retrieved from: http://heli.edu.au/wp-

- Murphy, J., Hofacker, C., \& Gretzel, U. (2017 $)$. Dawning of the Age of Robots in Hospitality and Tourism: Challenges for Teaching and Research. European Journal of Tourism Research, 15, 104-111.

- Murphy, J., Gretzel, U., \& Pesonen, J. (2019). Marketing robot services in hospitality and tourism: the role of anthropomorphism. Journal of Travel \& Tourism Marketing, 36(7), 784-795.

- Neapolitan, R. E., \& Jiang, X. (2013). Contemporary artificial intelligence. Boca Raton, FL: CRC Press.

- Ngai, E. W. T., Suk, F. F. C., \& Lo, S. Y. Y. (2008). Development of an RFIDbased sushi management system: The case of a conveyor-belt sushi restaurant. International Journal of Production Economics, 112(2), 630-645.

- Niininen, O; Buhalis, N; \& March, R, (2007) "Customer Empowerment in Tourism through Consumer Centric Marketing (CCM)", Qualitative Market Research: An International Journal, Vol. 10 Issue: 3, pp.265-281.

- Oztaysi, B; Baysan, S; and Akpınar, F, (2009). "Radio frequency identification (RFID) in hospitality," Technovation, vol. 29 pp. 618-624. 
- Perez, S. (2014). NoWait, The App That Lets You Join A Restaurant Wait List From Your Phone, Goes Nationwide. Retrieved on Abril 2020 from https://techcrunch.com/2014/01/30/nowait-theapp-that-lets-you-join-a-restaurantwait-list-from-yourphone-goes-nationwide/

- Qiu, H., Li, M., Shu, B., \& Bai, B. (2019). Enhancing hospitality experience with service robots: the mediating role of rapport building. Journal of Hospitality $\begin{array}{llll}\text { Marketing } \& \text { Management, } & \text { 1-22. Doi: }\end{array}$ https://doi.org/10.1080/19368623.2019.1645073.

- Rajesh, M. (2015). Inside Japan's first robot-staffed hotel. The Guardian. $\begin{array}{llll}\text { Retrieved on } & \text { August } & \text { From }\end{array}$ https://www.theguardian.com/travel/2015/aug/14/japan-henn-na-hotel-staffed-byrobots.

- Ritzer, G. (2015). Hospitality and presumption. Research in Hospitality Management, 5(1), 9-17.

- Rodriguez-Lizundia, E., Marcos, S., Zalama, E., Gómez-García-Bermejo, J., \& Gordaliza, A. (2015). A bellboyrobot: Study of the effects of robot behaviour on user engagementand comfort. International Journal of Human-Computer Studies, 82, 83-95.

- Russell, S., \& Norvig, P. (2010). Artificial intelligence: a modern approach (3rd ed). Upper Saddle River: Pearson Prentice Hall.

- Samani, H. (Ed.) (2016). Cognitive robotics. Boca Raton, FL: CRC Press.

- Schmid, P., \& Betsch, C. (2019). Effective Strategies for Rebutting Science Denialism in Public Discussions. Nat Hum Behav, 3(9), 931-9.

- Smirnova, M., Rebiazina, A. \& Frösén, J,( 2017), 'Customer Orientation as a Multidimensional Construct: Evidence From The Russian Markets', Journal of Business Research 86, 457-467. https://doi.org/10.1016/j.jbusres.2017.10.040.

- Tan, N., Mohan, R. E., \& Watanabe, A. (2016). Toward a framework for robotinclusive environments. Automation in Construction, 69, 68-78.

- Timms, M.J. (2016). Letting Artificial Intelligence in Education out of the Box: Educational Cobots and Smart Classrooms. International Journal of Artificial Intelligence in Education, 26(2), 701-712.

- Tom Dieck, C., Jung, T., \& Han, D.-I. (2016). Mapping requirements for the wearable smart glasses augmented reality museum application. Journal of Hospitality and Tourism Technology, 7(3), 230-253.

- Tong, W. (2015). Analyzing the Relationship between Customer Satisfaction and Customer Loyalty, Case: Ritz-Carlton Guangzhou. Bachelor's thesis of the Degree Programme in Business Management Bachelor Degree of Business Administration, TORNIO 2015, Available from: https://www.theseus.fi/bitstream/handle/10024/87964/THESIS.pdf?sequence=1", [Accessed on 23 - 09- 2019].

- Trejos, N. (2015). Marriott to hotel guests: We're app your service. USA Today. $\begin{array}{lll}\text { Retrieved } \quad \text { February } & \text { 2020, }\end{array}$ http://www.usatoday.com/story/travel/2015/05/13/marriott-hotels-mobilerequests-two-way-chat/27255025/ 
- Tung, S., \& Au, N. (2018). Exploring Customer Experiences with Robotics in Hospitality. International Journal of Contemporary Hospitality Management (in press), doi: https://doi.org/10.1108/IJCHM-06-2017-0322.

- Tung, S., \& Law, R. (2017). The potential for tourism and hospitality experience research in human-robot interactions. International Journal of Contemporary Hospitality Management, 29(10), 2498-2513.

- Tussyadiah P., \& Park S. (2018) Consumer Evaluation of Hotel Service Robots. In: Stangl B., Pesonen J. (eds) Information and Communication Technologies in Tourism 2018. Springer, Cham, pp. 308-320.

- Tussyadiah, P., Zach, F. K. \& Wang, J. (2017). Attitudes Toward Autonomous on Demand Mobility System: The Case of Self-Driving Taxi. In Schegg, R. \& Strangl, B. (Eds.) Information and Communication Technologies in Tourism 2017. Proceedings of the International Conference in Rome, Italy, January 24-26, 2017, pp. 755-766.

- Warwick, K. (2012). Artificial intelligence: The basics. Oxon: Routledge.

- Webster, C. \& Ivanov, S. (2020). Robots in travel, tourism and hospitality: Key findings from a global study . ISBN: 978-954-92786-8-2.

- World Health Organization (WHO). $\left(2020^{\mathrm{b}}\right)$. WHO Announces COVID-19 Outbreak a Pandemic? WHO, 12 March 2020, http://www.euro.who.int/en/healthtopics/health-emergencies/coronavirus-covid-19/news/news/2020/3/whoannounces-covid-19-outbreak-a-pandemic

- World Health Organization (2020 C) Coronavirus disease 2019 (COVID-19) Situation Report - 23- Data as reported by 12 February 2020.

- World Health Organization WHO $\left(2020^{\mathrm{A}}\right)$ Report of the WHO-China joint mission on coronavirus disease 2019 (COVID-19). WHO (www.who. int/docs/default-source/coronaviruse/who-china-joint-mission-on-covid-19-finalreport.pdf).

- World Health Organization $\left(2020^{\mathrm{d}}\right)$. Risk communication: Frequently asked questions,https://www.who.int/news-room/q-a-detail/risk-communicationfrequently-asked-questions.

- Youssef, A; Johnston, .J; AbdelHamid, A; Dakrory, I; \& Seddick, S, (2018), 'A Customer Engagement Framework for a B2B Context', Journal of Business \& Industrial Marketing 33(1), 145-152. https://doi.org/10.1108/JBIM-11-2017$\underline{0286}$. 


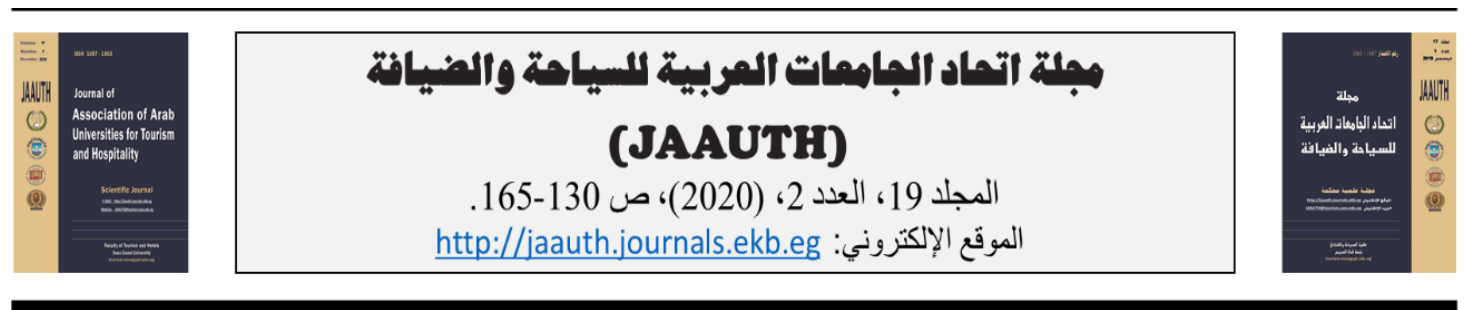

تأثير استخدام أتمتة الخدمة والتقنيات الروبوتية (SART) في الفنادق المصرية

$$
\text { هاني قزمال }
$$

قسم الدراسات الفندقية، المعهد العالي للسياحة والفنادق، الأقصر (إيجوث)، مصر

\section{البانص}

مقدمة: أصبحت أتمتة الخدمة والتقنيات الروبوتية من أهم التقنيات الاستراتيجية

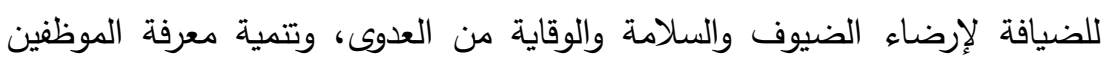

$$
\text { وكفاءتهم في صناعة الضيافة. }
$$

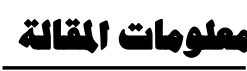

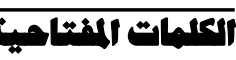

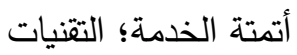

$$
\text { الروبوتية؛ رضا }
$$

الأهداف: دراسة تأثير استخدام أتمتة الخدمة والتقنيات الروبوتية (SART) في الضيف؛ التسويق

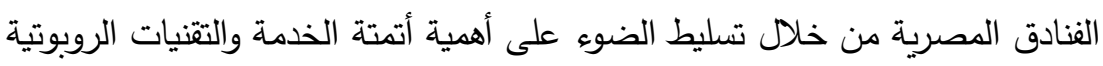

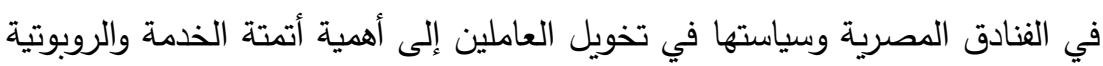
لضمان رضا النزلاء وسلامتهم. المنهجية: تم إجراء مسح على (28) فندقًا مصريًا من فئة الخمسة نجوم في القاهرة

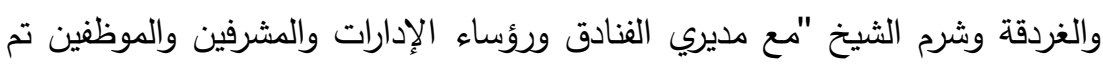

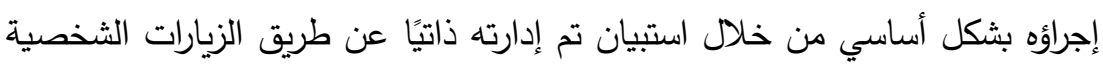

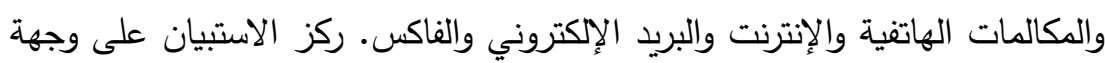

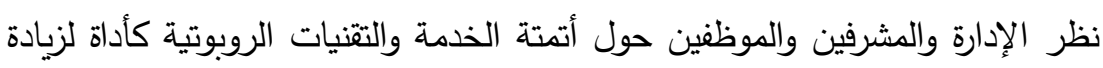
رضا الضيف وكذلك السلامة والوقاية من العدوى في مصر ، تم استخدام البيانات التي تم جمعها من عينة الفنادق المختارة. تم عمل تحليل وصفي للاستبيان باستخدام

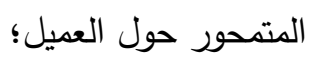
السلامة ومكافحة

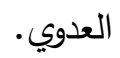

\section{(JAAUTH)}

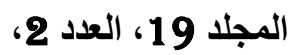
،(2020) ص ص 165-130

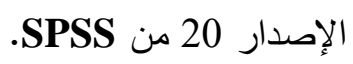

النتائج: أظهرت نتائج المساهمة الرئيسية لهذا البحث أن فاعلية أتمتة الخدمة

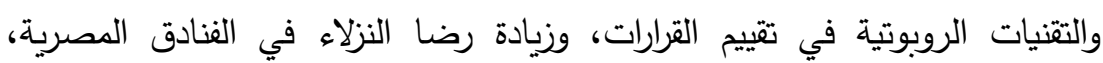

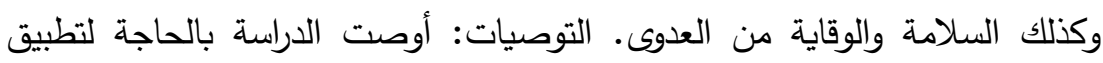

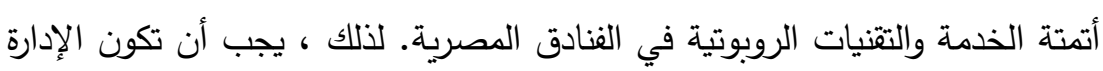

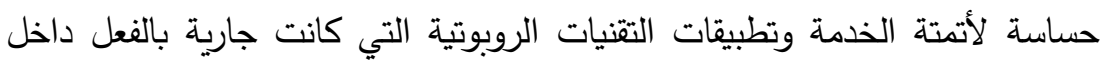

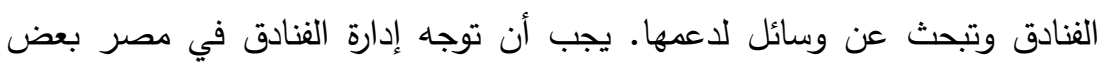
ميزانياتها لأتمتة الخدمة والتقنيات الروبوتية. 